University of Nebraska - Lincoln

DigitalCommons@University of Nebraska - Lincoln

Publications from USDA-ARS / UNL Faculty

U.S. Department of Agriculture: Agricultural

Research Service, Lincoln, Nebraska

April 2007

\title{
LOSS OF ALKALINE EARTH ELEMENTS BY RUNOFF FROM AGRICULTURAL WATERSHEDS
}

\author{
M. A. Elrashidi \\ USDA/NRCS \\ D. Hammer \\ USDA/NRCS \\ M. D. Mays \\ USDA/NRCS \\ C. A. Seybold \\ USDA/NRCS \\ S. D. Peaslee \\ USDA/NRCS
}

Follow this and additional works at: https://digitalcommons.unl.edu/usdaarsfacpub

Part of the Agricultural Science Commons

Elrashidi, M. A.; Hammer, D.; Mays, M. D.; Seybold, C. A.; and Peaslee, S. D., "LOSS OF ALKALINE EARTH ELEMENTS BY RUNOFF FROM AGRICULTURAL WATERSHEDS" (2007). Publications from USDA-ARS / UNL Faculty. 154.

https://digitalcommons.unl.edu/usdaarsfacpub/154

This Article is brought to you for free and open access by the U.S. Department of Agriculture: Agricultural Research Service, Lincoln, Nebraska at DigitalCommons@University of Nebraska - Lincoln. It has been accepted for inclusion in Publications from USDA-ARS / UNL Faculty by an authorized administrator of DigitalCommons@University of Nebraska - Lincoln. 


\title{
LOSS OF ALKALINE EARTH ELEMENTS BY RUNOFF FROM AGRICULTURAL WATERSHEDS
}

\author{
M. A. Elrashidi, D. Hammer, M. D. Mays, C. A. Seybold, and S. D. Peaslee
}

The loss of agricultural chemicals in runoff from agricultural land is a major cause of poor surface water quality in the United State. Scientists (Natural Resources Conservation Service) developed a technique using climatic, hydrologic, and soil survey information to estimate the impact of agricultural watersheds on natural water resources. The objective of this study was to apply this technique on the Wagon Train (WT) watershed to predict loss of alkaline earth elements (calcium [Ca], magnesium [Mg], barium [Ba], and strontium [Sr]) by runoff from soils and to estimate elements loading into WT reservoir. The predicted losses of $\mathrm{Ca}, \mathrm{Mg}, \mathrm{Ba}$, and $\mathrm{Sr}$ by runoff were $67.5,19.9,0.17$, and $0.05 \mathrm{~kg} \mathrm{ha}^{-1}$ $\mathrm{yr}^{-1}$, respectively. These data give a total annual loss of 262.1 and 77.1 $\mathrm{Mg}$ of $\mathrm{Ca}$ and $\mathrm{Mg}$, respectively, for the entire watershed and could be considered as the annual loading for WT reservoir. The total annual loss was $668 \mathrm{~kg}$ for $\mathrm{Ba}$ and $186 \mathrm{~kg}$ for $\mathrm{Sr}$ and could represent the annual loading for the reservoir. The predicted $\mathrm{Ca}, \mathrm{Mg}$, and $\mathrm{Ba}$ concentrations in runoff were in good agreement with those observed in water samples collected weekly from the main stream in the watershed. However, the predicted Sr concentration in runoff was much less than that observed in the stream water. Subsurface seepage into the stream might contribute to the high $\mathrm{Sr}$ concentration observed in the stream water. We concluded that the technique could provide a reasonable estimation of $\mathrm{Ca}, \mathrm{Mg}$, and Ba losses in runoff from agricultural watersheds and loading into surface water bodies. (Soil Science 2007;172:313-332)

Key words: Alkaline earth elements, runoff, barium, calcium, magnesium, strontium, agricultural watershed.

A LKALINE earth elements (AEEs: calcium [Ca], magnesium $[\mathrm{Mg}]$, barium $[\mathrm{Ba}]$, and strontium [Sr]) share many chemical properties that identify them as a chemical group in soils. These properties contribute to their natural occurrence in carbonate, phosphate, sulfate, and silicate minerals and to their participation in many similar chemical reactions. Calcium and $\mathrm{Mg}$ are the most common of the AEEs in soils (Suarez, 1996). Major Ca minerals include calcite, dolomite, gypsum, and apatite. Dolomite, talc, brucite, chlorite, tourmaline, and magnesite are the main $\mathrm{Mg}$ minerals in soils.

USDA/NRCS, National Soil Survey Center, 100 Centennial Mall North, Lincoln, NE 68508-3866. Dr. Elrashidi is corresponding author. E-mail: moustafa.elrashidi@lin.usda.gov

Received June 28, 2006; accepted Dec. 6, 2006.

DOl: 10.1097/SS.0b013e31803105be
Barium and $\mathrm{Sr}$ have a much lower abundance in soils than $\mathrm{Ca}$ and $\mathrm{Mg}$. Barium is most often found in soils as barite $\left(\mathrm{BaSO}_{4}\right)$ and witherite $\left(\mathrm{BaCO}_{3}\right)$ minerals. However, $\mathrm{Ba}$ is usually present as a trace constituent in silicate minerals such as feldspars and micas. Strontium forms celestite $\left(\mathrm{SrSO}_{4}\right)$ and strontianite $\left(\mathrm{SrCO}_{3}\right) \mathrm{min}-$ erals in soils. Similar to $\mathrm{Ba}$, feldspars are the major host minerals of $\mathrm{Sr}$.

Heavy storms may generate runoff events that remove soil chemical constituents from agricultural land and transport them to surface water bodies (nonpoint source of contamination). Most AEEs input to streams, rivers, and lakes are from weathering and dissolution of carbonate, sulfate, and silicate minerals in soils (Brass, 1976; Garrels and Perry, 1974). Losses of AEEs from agricultural land through runoff have received little attention from agronomists and 
soil scientists. However, from an environmental water quality view point, AEEs concentration and form as well as total quantity lost from nonpoint sources are important concerns for both agricultural management and subsequent water users.

Excessively large concentrations of AEEs are objectionable in drinking water because of possible physiological effects, unpleasant taste, and greater costs due to corrosion or the need for additional treatment (U.S. Environmental Protection Agency [USEPA], 1986). Calcium and $\mathrm{Mg}$ contribute to the hardness of the water and tend to cause encrustations on cooking utensils, pipes, and in water heaters (Hem, 1989). Large concentrations of $\mathrm{Ba}$ in drinking water can cause health problems for human and animals. To protect human health, the USEPA (2003) allows no more than $2 \mathrm{mg} \mathrm{L}^{-1}$ of $\mathrm{Ba}$ in drinking water sources. Introduction of $\mathrm{Sr}$ in atmosphere due to nuclear weapons testing and subsequent fallout on agricultural land and natural water resources increased the concern for the adverse effects on human and animal health (Suarez, 1996). Strontium is of particular concern because of the radioisotope strontium Sr 90, which readily enters the food chain (Bowen and Dymond, 1956).

Managing nonpoint sources of contamination from agricultural land is technically complex. Contamination sources often are located over a large geographic area and are difficult to identify. Identifying hot spots within a watershed enable more efficient use of funds to alleviate potential problems and protect water resources. There are good models that can estimate the impact of nonpoint sources of contamination from agricultural watersheds. But these models are too complex and expensive because they require very extensive data input. The U.S. Department of Agriculture Natural Resources Conservation Service (USDA/NRCS) developed an exploratory technique (Elrashidi et al., 2004, 2005a, $2005 \mathrm{~b}$ ) to estimate elements loss by runoff for agricultural watersheds. The technique is quick and cost-effective because it utilizes existing climatic, hydrologic, and soil survey databases.

The NRCS technique applies the USDA runoff equation (USDA/SCS, 1991) to estimate loss of runoff water from soils by rainfall. The technique assumes that soluble elements such as $\mathrm{Ca}, \mathrm{Mg}, \mathrm{Ba}$, and $\mathrm{Sr}$ are lost from a specific depth of surface soil that interacts with runoff and leaching water. A brief description of the technique is reported in Materials and Methods. The objectives of this study were to apply this technique on a watershed (Wagon Train [WT]) in southeast Nebraska to estimate (i) losses of $\mathrm{Ca}, \mathrm{Mg}, \mathrm{Ba}$, and $\mathrm{Sr}$ from soils by runoff and (ii) elements loading into WT reservoir.

\section{MATERIALS AND METHODS}

\section{Wagon Train Watershed}

Wagon Train watershed has a 315-acre (128 ha) reservoir located on the Hickman Branch of Salt Creek (Platte River Basin) in Lancaster County, Nebraska (Fig. 1). The reservoir was constructed primarily as a flood control structure by the U.S. Army Corps of Engineers in 1962. The total drainage area encompass 9984 acres (4042 ha) of agricultural land. Most of the area $(70 \%)$ is cultivated with crops (soybean, Glycine willd; corn, Zea mays L.; wheat, Triticum aestivum L.; sunflower, Helianthus sp. L.; alfalfa, Medicago sativa L.). The rest of the watershed is mostly covered with grassland, whereas forestland, wetland, and urban development account for small areas.

The watershed topography is moderately sloping. The land relief consists of uplands, stream terraces, and bottom lands. There are 33 miles $(53 \mathrm{~km})$ of streams in the watershed, and 40 ponds ranging from 0.3 to 6.5 acres $(0.12-2.6 \mathrm{ha})$. Overland flow enters the reservoir through intermittent tributaries. From the dam, the water flows into the Hickman Branch of Salt Creek, which flows west and north through Lincoln, and eventually to the Platte River near Ashland, Nebraska.

We used soil associations on the general soil map in the Soil Survey Report of Lancaster County, Nebraska (Brown et al., 1980), to determine the major soil series and phases in WT watershed. Nine soil series (Wymore, Pawnee, Nodaway, Sharpsburg, Mayberry, Colo, Judson, Burchard, and Kennebec) account for $96.1 \%$ of the agricultural land. Nearly three quarters of the watershed consist of Wymore and Pawnee soils.

\section{Soil and Water Sampling}

Soil sampling included each of three widely existent phases of Wymore soil series (WtB, $\mathrm{WtC} 2$, and $\mathrm{WtD} 3$ ) and accounted for $66 \%$ of the agricultural land in the watershed and two phases of Pawnee (Pawnee-PaC2 and-PaD2) along with the other seven soil series. This 


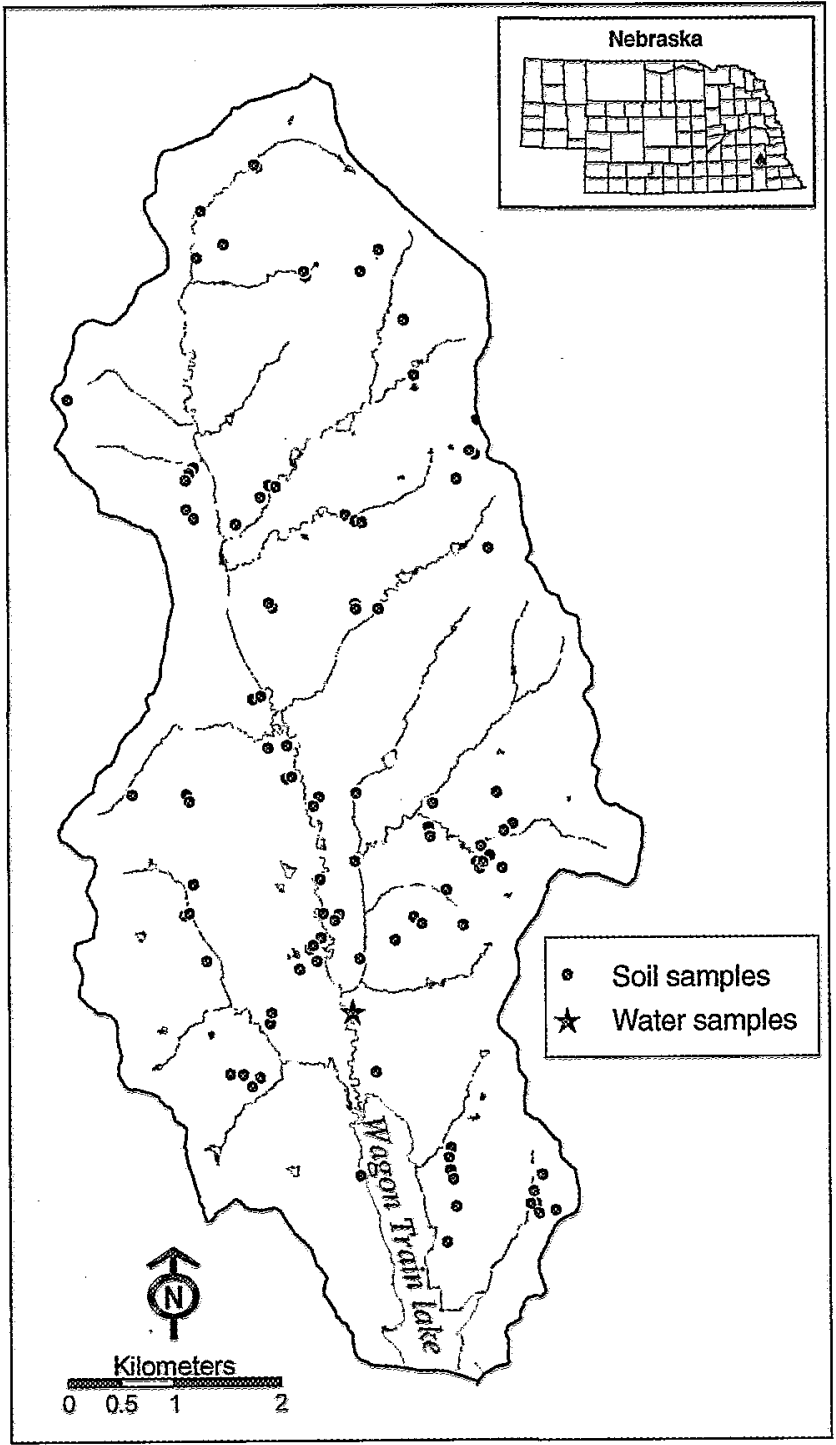

Fig. 1. Soil and water sampling locations in WT watershed, Lancaster County, Nebraska.

approach produced a total of 12 soil map units (SMUs) that were sampled. Soil samples were collected from cropland and grassland within each map unit. Recently, updated soil survey activities have split Sharpsburg into three soil series (Tomek, Yutan, and Aksarben). The new classification, however, should not affect results given in this study.

Representative soil samples were taken from each of the 12 SMUs. To distribute sampling locations evenly within the agricultural area, the watershed was divided into six sections. An equal number of samples were taken at random from each section. For each SMU, six samples were collected from cropland and two samples from grassland. In total, 72 soil samples from cropland and 24 from grassland were collected (Fig. 1).

At the randomly selected sampling sites, three cores were taken from the top 30-cm soil layer and mixed thoroughly in a stainless steel tray. Approximately, a $2-\mathrm{kg}$ composite sample was packed in a plastic bag and sealed. Sampling was completed during April of 2003 before fertilizer application for the summer crop.

Many small streams receive surface water runoff from the agricultural land in the watershed. Eventually, streams located northerly of the reservoir join in a single stream that runs southerly about $0.5 \mathrm{~km}$ before entering the 
reservoir near the north edge. Water samples taken along the main stream (just before discharging into the reservoir) were assumed to represent the surface water runoff generated from the entire watershed.

Most of the surface water runoff from the agricultural land in WT watershed and water inflow for WT reservoir are expected during the rainy season in the spring, summer, and fall (March through November). During the period from March through November, weekly water samples were collected from the main stream (Fig. 1). The analysis for major streams proved that samples taken from the main stream are representative of runoff generated from the entire watershed (Elrashidi et al., 2005a, 2005b).

Water samples were taken from the stream under base flow conditions with almost no suspended particulates. Samples were collected (grab) in midstream, by using $1-\mathrm{L}$ polyethylene bottles that have been rinsed twice with stream water before sample collection. The water samples were taken immediately to the labora- tory and refrigerated at $4^{\circ} \mathrm{C}$. The water analysis was completed within a week. The soil and water sampling locations are shown in Figure 1.

\section{Soil and Water Analysis}

Soil samples were analyzed on air-dried, $<2-\mathrm{mm}$ soil by methods described in Soil Survey Investigations Report No. 42 (USDA/NRCS, 2004). Alphanumeric codes in parentheses next to each method represent specific standard operating procedures. Particle-size analysis was performed by sieve and pipette method (3A1). Cation exchange capacity was conducted by $\mathrm{NH}_{4} \mathrm{OAc}$ buffered at $\mathrm{pH} 7.0$ (5A8b). Total carbon (C) content was determined by dry combustion (6A2f) (Vario EL III; Elementar Americanas, Mt. Laurel, New Jersey), and $\mathrm{CaCO}_{3}$ equivalent was estimated by electronic manometer method (6E1g). Organic $C$ in soil was estimated from both the total $\mathrm{C}$ and $\mathrm{CaCO}_{3}$-C. Soil $\mathrm{pH}$ was measured in a $1: 1$ soil/water suspension (8C1f). Liquid Limit was determined by the American Society for Testing and Materials method D 4318 (ASTM, 1993).

TABLE 1

Soil classification and selected properties for 12 major soils under crop and grass cover in WT watershed, Lancaster County, Nebraska

\begin{tabular}{|c|c|c|c|c|c|c|c|c|}
\hline Soil map unit & Classification & Land use & $\begin{array}{l}\text { Clay } \\
(\%)\end{array}$ & $\begin{array}{l}\mathrm{OM} \\
(\%)\end{array}$ & $\begin{array}{c}\text { CEC } \\
\left(\mathrm{cmol} \mathrm{kg}^{-1}\right)\end{array}$ & $\mathrm{pH}$ water & $\begin{array}{l}\text { Liquid limit } \\
\text { (mL kg-1 of soil) }\end{array}$ & $\begin{array}{c}\begin{array}{c}\text { Hydrologic } \\
\text { group }\end{array} \\
\end{array}$ \\
\hline \multirow[t]{2}{*}{ Wymore (WtB) } & \multirow{2}{*}{$\begin{array}{l}\text { Fine, montmorillonitic, } \\
\text { mesic Aquic Argiudolls }\end{array}$} & Cropland & 37.3 & 2.14 & 25.90 & 5.56 & 465 & $\mathrm{D}$ \\
\hline & & Grassland & 32.9 & 2.44 & 25.70 & 5.90 & 465 & $\mathrm{D}$ \\
\hline \multirow[t]{2}{*}{ Wymore (WtC2) } & \multirow{2}{*}{$\begin{array}{l}\text { Fine, montmorillonitic, } \\
\text { mesic Aquic Argiudolls }\end{array}$} & Cropland & 37.9 & 2.23 & 26.50 & 5.70 & 465 & $\mathrm{D}$ \\
\hline & & Grassland & 35.6 & 3.46 & 28.20 & 5.80 & 465 & $\mathrm{D}$ \\
\hline \multirow[t]{2}{*}{ Wymore (WtD3) } & \multirow{2}{*}{$\begin{array}{l}\text { Fine, montmorillonitic, } \\
\text { mesic Aquic Argiudolls }\end{array}$} & Cropland & 41.2 & 2.16 & 29.30 & 5.85 & 465 & $\mathrm{D}$ \\
\hline & & Grassland & 34.2 & 2.78 & 28.90 & 6.40 & 465 & $\mathrm{D}$ \\
\hline \multirow[t]{2}{*}{ Pawnee ( $\mathrm{PaC} 2)$} & \multirow{2}{*}{$\begin{array}{l}\text { Fine, montmorillonitic, } \\
\text { mesic Aquic Argiudolls }\end{array}$} & Cropland & 35.2 & 1.94 & 24.90 & 5.64 & 475 & $\mathrm{D}$ \\
\hline & & Grassland & 29.3 & 2.38 & 21.70 & 5.55 & $\dot{4} 75$ & $\mathrm{D}$ \\
\hline \multirow[t]{2}{*}{ Pawnee $(\mathrm{PaD} 2)$} & \multirow{2}{*}{$\begin{array}{l}\text { Fine, montmorillonitic, } \\
\text { mesic Aquic Argiudolls }\end{array}$} & Cropland & 34.9 & 1.85 & 24.50 & 5.79 & 475 & $\mathrm{D}$ \\
\hline & & Grassland & 34.7 & 2.39 & 25.50 & 6.10 & 475 & $\mathrm{D}$ \\
\hline \multirow{2}{*}{$\begin{array}{l}\text { Nodaway } \\
\text { (No, Ns) }\end{array}$} & \multirow{2}{*}{$\begin{array}{l}\text { Fine-silty, mixed, } \\
\text { nonacid, mesic Mollic } \\
\text { Udifluvents }\end{array}$} & Cropland & 29.4 & 2.08 & 24.40 & 6.58 & 300 & $B$ \\
\hline & & Grassland & 30.1 & 2.97 & 26.40 & 6.25 & 300 & $\mathrm{~B}$ \\
\hline \multirow{2}{*}{$\begin{array}{l}\text { Sharpsburg (ShC, } \\
\text { ShD, ShD2) }\end{array}$} & \multirow{2}{*}{$\begin{array}{l}\text { Fine, montmorillonitic, } \\
\text { mesic Typic Argiudolls }\end{array}$} & Cropland & 39.7 & 1.94 & 27.60 & 5.70 & 450 & $\mathrm{~B}$ \\
\hline & & Grassland & 37.4 & 2.05 & 27.00 & 6.15 & 450 & $\mathrm{~B}$ \\
\hline \multirow{2}{*}{$\begin{array}{l}\text { Mayberry (MeC2, } \\
\text { MeD2, MhC3) }\end{array}$} & \multirow{2}{*}{$\begin{array}{l}\text { Fine, montmorillonitic, } \\
\text { mesic Aquic Argiudolls }\end{array}$} & Cropland & 31.8 & 1.96 & 22.80 & 5.99 & 400 & $\mathrm{D}$ \\
\hline & & Grassland & 26.0 & 2.08 & 20.40 & 6.50 & 400 & $\mathrm{D}$ \\
\hline \multirow[t]{2}{*}{ Colo $(\mathrm{Co}, \mathrm{Cp})$} & Fine-silty, mixed, mesic & Cropland & 32.1 & 2.13 & 25.00 & 6.30 & 500 & $\mathrm{C}$ \\
\hline & Cumulic Hapludolls & Grassland & 29.0 & 2.95 & 26.10 & 6.10 & 500 & $\mathrm{C}$ \\
\hline \multirow[t]{2}{*}{ Judson (JuC) } & Fine-silty, mixed, mesic & Cropland & 32.0 & 2.26 & 24.80 & 6.05 & 378 & $\mathrm{~B}$ \\
\hline & Cumulic Hapludolls & Grassland & 30.5 & 3.06 & 24.00 & 6.00 & 378 & $\mathrm{~B}$ \\
\hline \multirow{2}{*}{$\begin{array}{l}\text { Burchard (BpF, } \\
\text { BrD, BrE) }\end{array}$} & \multirow{2}{*}{$\begin{array}{l}\text { Fine-loamy, mixed, } \\
\text { mesic Typic Argiudolls }\end{array}$} & Cropland & 29.8 & 1.89 & 21.70 & 5.96 & 425 & B \\
\hline & & Grassland & 30.1 & 2.99 & 23.10 & 7.00 & 425 & B \\
\hline \multirow[t]{2}{*}{ Kennebec (Ke) } & Fine-silty, mixed, mesic & Cropland & 27.6 & 1.94 & 20.70 & 5.95 & .350 & B \\
\hline & Cumulic Hapludolls & Grassland & 24.7 & 2.09 & 19.50 & 6.10 & 350 & B \\
\hline
\end{tabular}

$\mathrm{CEC}=$ cation exchange capacity. 
Classification, and selected properties for soils under crop and grass in WT watershed are given in Table 1. Environmental water-extractable AEEs (Ca, $\mathrm{Mg}, \mathrm{Ba}$, and $\mathrm{Sr}$ ) for soils were determined according to the Soil Survey Laboratory procedure (4D2b1) (USDA/NRCS, 2004). In this method (4D2b1), the soil/water system (20 g of soil and $100 \mathrm{~mL}$ of distilled water) was allowed to equilibrate at room temperature for 23 hours before shaking the suspension for 1 hour. The supernatant was passed through $0.45-\mu \mathrm{m}$ filter. Elements were determined in the filtrate by the inductively coupled plasma-optical emission spectrometry (Perkin-Elmer 3300 DV, Wellesley, MA).

Stream water samples were filtered with a glass syringe equipped with Whatman $25-\mathrm{mm}$ GD/X disposable nylon filter media $(0.45 \mu \mathrm{m}$ pore size). Alkaline earth elements concentration in the filtrate was determined by the inductively coupled plasma-optical emission spectrometry (Perkin-Elmer 3300 DV; 4I3a). The $\mathrm{pH}$ of the filtrate was determined by the combination electrode and digital $\mathrm{pH} /$ ion meter, Model 950, Fisher Scientific (8C1a) as described in USDA/NRCS (2004).

\section{Estimation of Runoff Water}

Rainfall is the primary source of water that runs off the surface of these small agxicultural watersheds. The main factors affecting the volume of rainfall that runs off are the kind of soil and the type of vegetation in the watershed (USDA/SCS, 1991). The runoff equation can be written as follows:

$$
\mathrm{Q}=(R-0.2 S)^{2} \div(R+0.8 S)
$$

where $Q=$ runoff (inches), $R=$ rainfall (inches), and $S=$ potential maximum retention (inches) after runoff begins.

The potential maximum retention $(S)$ can range from zero on a smooth and impervious surface to infinity in deep gravel. The $S$ value is converted to a runoff curve number $(\mathrm{CN})$, which is dependent on both the hydrologic soil group and type of land cover by the following equation:

$$
\mathrm{CN}=1000 \div(10+S)
$$

According to Eq. (2), the $\mathrm{CN}$ is 100 when $S$ is. 0 and approaches 0 as $S$ approaches infinity. Runoff CNs can be any value from zero to 100 , but for practical applications are limited to a range of 40 to 98 . Substituting Eq. (2) into Eq. (1) gives

$$
\begin{aligned}
\mathrm{Q} & =R-\{[2(100-\mathrm{CN}) / \mathrm{CN}]\}^{2} \div\{R \\
& +[8(100-\mathrm{CN}) / \mathrm{CN}]\}
\end{aligned}
$$

In this study, hydrologic groups of the 12 SMUs investigated were used to determine CNs for crop (cropland) and grass (grassland). Further, the annual rainfall at various soil locations were taken from the USDA/NRCS National Water and Climate Center (NWCC, 2003).

\begin{tabular}{|c|c|c|c|c|c|c|}
\hline \multirow{3}{*}{ Soil map unit } & \multicolumn{2}{|c|}{ Area } & \multicolumn{2}{|c|}{ Runoff* } & \multicolumn{2}{|c|}{ Interaction zone } \\
\hline & Cropland & Grassland & Cropland & Grassland & Cropland & Grassland \\
\hline & \multicolumn{2}{|c|}{$\ldots-\ldots$ (ha) $-\ldots \ldots$} & \multicolumn{4}{|c|}{$\ldots \ldots \ldots\left(\mathrm{m}^{3} \mathrm{ha}^{-1} \mathrm{yr}^{-1}\right) \ldots \ldots$} \\
\hline Wymore (WtB) & 391 & 167 & 1167 & 1004 & 59.5 & 59.5 \\
\hline Wymore (WtC2) & 1270 & 544 & 1167 & 1004 & 59.5 & 59.5 \\
\hline Wymore (WtD3) & 124 & 53 & 1167 & 1004 & 59.5 & 59.5 \\
\hline Pawnee $(\mathrm{PaC} 2)$ & 240 & 103 & 1167 & 1004 & $60: 8$ & 60.8 \\
\hline Pawnee ( $\mathrm{PaD} 2)$ & 54 & 23 & 1167 & 1004 & 60.8 & 60.8 \\
\hline Nodaway (No, Ns) & 142 & 61 & 901 & 638 & 38.4 & 38.4 \\
\hline Sharpsburg (ShC, ShD, ShD2) & 124 & 53 & 901 & 638 & 57.6 & 57.6 \\
\hline Mayberry (MeC2, MeD2, MhC3) & 110 & 47 & 1167 & 1004 & 51.2 & 51.2 \\
\hline Colo $(\mathrm{Co}, \mathrm{Cp})$ & 107 & 46 & 1084 & 876 & 64.0 & 64.0 \\
\hline Judson $(\mathrm{JuC})$ & 71 & 30 & 901 & 638 & 48.4 & 48.4 \\
\hline Burchard (BpF, BrD, BrE) & 57 & 24 & 901 & 638 & 54.4 & 54.4 \\
\hline Kennebec $(\mathrm{Ke})$ & 31 & 13 & 901 & 638 & 44.8 & 44.8 \\
\hline Weighted average & & & 1122 & 942 & 57.7 & 57.7 \\
\hline Total & 2719 & 1165 & $3,050,750$ & $1,097,609$ & 156,976 & 67,275 \\
\hline
\end{tabular}

TABLE 2

Predicted annual loss of runoff water and water presents in interaction zone for 12 major soils under crop and grass in WT watershed, Lancaster County, Nebraska

*USDA/SCS (1991). 
USDA/SCS (1991) developed the runoff equation, Eq. (3), to estimate runoff from small agricultural watersheds by 24 -hour rainfall event. It was assumed the 24-hour storm was an effective rainfall $(R)$ that could generate runoff. In this study, however, we applied the runoff equation to estimate runoff from an annual rainfall. It was assumed $20 \%$ of the annual rainfall in Lancaster County $(730 \mathrm{~mm})$ would generate runoff. The effective rain $(R)=$ (annual rainfall/5), which is based on the average annual runoff of the United States, 1951-1980 (Gilbert et al., 1987). This approach has an insignificant effect on runoff value derived from the runoff equation, Eq. (3), because of the similarity of the effective rain value $(R)$ used in both cases. Consequently, it enables us to predict runoff water for an annual rainfall rather than a storm event, which is desirable to the scientific and agricultural communities.

For each soil, both the runoff $\mathrm{CN}$ and effective rainfall $(R)$ values were applied in the runoff equation, Eq. (3), to calculate the runoff (Q) for cropland and grassland. Noteworthy, Eq. (3) calculated runoff values in inches. In this study, the $Q$ values were converted to millimeters.

\section{Observed Inflow for WT Reservoir}

In 1962, the dam on a tributary of Salt Creek and construction of the WT reservoir were completed. However, U.S. Geological Survey (USGS, 2001) has monitored the water flow in Salt Creek and streams in the Platte River basin long before the construction of WT reservoir. The Salt Creek gauge at Roca (USGS gauge 06803000, hydrologic unit 10200203, Lancaster County, Nebraska) with a period of record from 1951 to 2000 provided average monthly water flow rate values for a drainage area of 106,880 acre $(43,286 \mathrm{ha}$ ) encompassing WT watershed (USGS, 2001). Recently, the Lower Platte South Natural Resources District (LPSNRD, 2004) used the ratio of the watershed to the Salt Creek drainage area (9.34\%) to calculate the average monthly water flow rate values for WT watershed. In this study, we used these average monthly water flow rate values to calculate the observed inflow for WT reservoir.

\section{Estimating Elements Loss by Runoff}

Nutrients such as $\mathrm{N}, \mathrm{K}, \mathrm{P}$, and other agricultural chemicals are released from a thin layer of surface soil that interacts with rainfall and runoff. In chemical transport models, the thickness of the interaction zone is determined by model calibration with experimental data, with depths ranging between 2.0 and $6.0 \mathrm{~mm}$ (Donigian et al., 1977). Frere et al. (1980), however, suggested an interaction zone of 10 $\mathrm{mm}$, assuming that only a fraction of the chemical present in this depth interacts with rainfall water. In other studies in this laboratory, Elrashidi et al. (2003, 2004, 2005a, 2005b) used a fixed soil thickness of $10 \mathrm{~mm}$ to estimate $P$ and nitrate- $\mathrm{N}$ loss by runoff for agricultural land.

In this study, we used an interaction zone of $10 \mathrm{~mm}$ to calculate the amount of $\mathrm{Ca}, \mathrm{Mg}, \mathrm{Ba}$, and $\mathrm{Sr}$ released from surface soils by runoff. Also, it was assumed that during the runoff occurrence, water content in the surface $10-\mathrm{mm}$ soil depth is at the liquid limit, the moisture content at which the soil passes from a plastic to a liquid state. Thus, during the runoff occurrence, the total amount of water (where AEEs in the $10-\mathrm{mm}$ soil depth is dissolved) is the sum of water within the top $10-\mathrm{mm}$ of soil (liquid limit) and that on the surface of soil (runoff water). The volume of water in the $10-\mathrm{mm}$ soil depth (interaction zone) is usually very small when compared with runoff water (Table 2). The average water content in the soils interaction zone is $5.1 \%$ and $6.1 \%$ of the runoff water for cropland and grassland, respectively. Only elements in runoff water are removed and lost during the runoff occurrence. For the 12 map units investigated, annual amounts of elements loss by runoff were calculated as kilograms or grams per hectare.

\section{Removal of $\mathrm{Ca}$ and $\mathrm{Mg}$ in Runoff}

Using the data on runoff water losses from the 12 SMUs (Table 2), and the amount of elements $(\mathrm{Ca}$ and $\mathrm{Mg}$ ) present in both water and exchangeable phases in soils (Table 3 and 4), we calculated how the removal of element from both the water and exchangeable phases affect the concentration in runoff water. The calculation for $\mathrm{Ca}$ could be outlined as follows.

1) For each SMU, the amount of Ca removed in runoff was calculated (kilograms per SMU) when $\mathrm{N} \%$ of the exchangeable $\mathrm{Ca}$ in soil (interaction zone) is released to the water phase. $\mathrm{N}$ is any number between 0 and 100 .

2) Calcium removed in runoff from SMUs calculated in step 1 were summed up $\left(R_{\mathrm{N}}\right)$ to determine the total amount of 
TABLE 3

Average and S.D. of dissolved $\mathrm{Ca}, \mathrm{Mg}, \mathrm{Ba}$, and $\mathrm{Sr}$ in water phase for 12 major soils under crop and grass in WT watershed, Lancaster County, Nebraska

\begin{tabular}{|c|c|c|c|c|c|c|c|c|}
\hline \multirow{3}{*}{ Soil map unit } & \multicolumn{2}{|c|}{$\mathrm{Ca}$} & \multicolumn{2}{|c|}{$\mathrm{Mg}$} & \multicolumn{2}{|c|}{$\mathrm{Ba}$} & \multicolumn{2}{|c|}{$\mathrm{Sr}$} \\
\hline & Cropland & Grassland & Cropland & Grassland & Cropland & Grassland & Cropland & Grassland \\
\hline & \multicolumn{4}{|c|}{$\ldots \ldots\left(\mathrm{mg} \mathrm{kg}^{-1}\right) \ldots \ldots$} & \multicolumn{4}{|c|}{$\ldots \ldots \ldots\left(\mu \mathrm{kg}^{-1}\right) \ldots \ldots$} \\
\hline \multicolumn{9}{|l|}{ Wymore (WtB) } \\
\hline Average & 70.62 & 48.93 & 37.06 & 30.18 & 1508.14 & 1325.74 & 248.79 & 326.78 \\
\hline \multirow{2}{*}{\multicolumn{9}{|c|}{ Wymore (WtC2) }} \\
\hline & & & & & & & & \\
\hline Average & 84.26 & 61.38 & 47.56 & 21.15 & 1748.33 & 873.60 & 478.97 & 375.90 \\
\hline S.D. & 66.66 & 9.50 & 20.17 & 2.36 & 968.41 & 276.03 & 262.24 & 4.00 \\
\hline \multicolumn{9}{|c|}{ Wymore (WtD3) } \\
\hline Average & 50.16 & 90.72 & 41.77 & 54.21 & 1881.71 & 2147.13 & 358.33 & 655.11 \\
\hline S.D. & 27.53 & 4.21 & 12.13 & 19.15 & 626.40 & 713.46 & 123.16 & 119.27 \\
\hline \multicolumn{9}{|l|}{ Pawnee $(\mathrm{PaC} 2)$} \\
\hline Average & 49.96 & 33.08 & 31.93 & 22.71 & 1234.96 & 935.71 & 329.92 & 229.76 \\
\hline S.D. & 19.16 & 2.02 & 18.46 & 9.93 & 771.85 & 520.82 & 163.34 & 15.41 \\
\hline \multicolumn{9}{|l|}{ Pawnee (PaD2) } \\
\hline Average & 50.84 & 69.75 & 43.50 & 45.04 & 1564.70 & 1606.08 & 332.83 & 500.62 \\
\hline S.D. & 17.13 & 26.39 & 13.77 & 16.16 & 588.05 & 729.33 & 76.48 & 229.63 \\
\hline \multicolumn{9}{|l|}{ Nodaway } \\
\hline Average & 67.00 & 73.67 & 27.17 & 36.49 & 944.75 & 1615.56 & 369.45 & 493.53 \\
\hline S.D. & 32.02 & 14.26 & 15.05 & 10.92 & 667.10 & 882.68 & 173.55 & 52.24 \\
\hline \multicolumn{9}{|l|}{ Sharpsburg } \\
\hline Average & 80.72 & 61.48 & 44.48 & 39.81 & 1781.71 & 1560.00 & 316.74 & 445.59 \\
\hline S.D. & 71.59 & 14.27 & 12.68 & 16.33 & 743.27 & 1032.44 & 172.65 & \\
\hline \multicolumn{9}{|l|}{ Mayberry } \\
\hline Average & 59.43 & 65.79 & 37.59 & 20.62 & 1308.31 & 729.77 & 327.16 & 269.13 \\
\hline S.D. & 26.90 & 5.19 & 16.41 & 7.04 & 815.83 & 256.56 & 140.49 & 36.19 \\
\hline \multicolumn{9}{|l|}{ Colo } \\
\hline Average & 93.75 & 112.69 & 37.10 & 43.40 & 1162.04 & 1458.42 & 526.72 & 542.29 \\
\hline S.D. & 58.38 & 4.18 & 13.02 & 3.67 & 515.83 & 294.69 & 294.60 & 21.16 \\
\hline \multicolumn{9}{|l|}{ Judson } \\
\hline Average & 54.62 & 47.37 & 27.72 & 18.54 & 940.16 & 706.59 & 327.40 & 290.62 \\
\hline S.D. & 16.19 & 14.03 & 11.09 & 2.67 & 350.10 & 48.60 & 100.91 & 65.48 \\
\hline \multicolumn{9}{|l|}{ Burchard } \\
\hline Average & 51.77 & 160.98 & 39.13 & 16.07 & 1465.58 & 514.40 & 329.04 & 376.21 \\
\hline S.D. & 15.97 & 65.79 & 20.06 & 10.60 & 726.07 & 303.86 & 177.07 & 179.75 \\
\hline \multicolumn{9}{|l|}{ Kennebec } \\
\hline Average & 41.71 & 50.10 & 27.93 & 17.23 & 999.94 & 742.45 & 279.53 & $\cdot 260.11$ \\
\hline S.D. & 11.69 & 20.55 & 8.77 & 6.46 & 368.62 & 283.57 & 85.74 & 39.88 \\
\hline
\end{tabular}

exchangeable $\mathrm{Ca}(\mathrm{kg})$ removed in runoff generated from the entire watershed as follows:

$$
\sum S M U=R_{N}(k g)
$$

3) For each SMU, the amount of water-soluble $\mathrm{Ca}$ was calculated (kilograms per SMU) when the element present in the water phase of soil (interaction zone) is removed in runoff.

4) Calcium removed in runoff from SMUs calculated in step 3 were summed up $(W)$ to determine the total amount of water- soluble $\mathrm{Ca}(\mathrm{kg})$ removed in runoff generated from the watershed as follows:

$$
\sum S M U=W(\mathrm{~kg})
$$

5) The average Ca concentration in runoff (Runoff Ca) generated from the entire watershed was calculated (milligrams per liter), when both $\mathrm{Ca}$ present in the water phase and $\mathrm{N} \%$ of the exchangeable $\mathrm{Ca}$ in soil (interaction zone) are removed in runoff water as follows:

$$
R \text { imnoff } \mathrm{Ca}\left(m g L^{-1}\right)=\left[\left(R_{N}+W\right) \times 1000\right] \div(V)(6)
$$

where $V$ is the total volume of runoff water generated from the entire watershed (cubic meter). 
TABLE 4

Average and S.D. of $\mathrm{Ca}$ and $\mathrm{Mg}$ in exchangeable phase for 12 major soils under crop and grass in WT watershed, Lancaster County, Nebraska

\begin{tabular}{|c|c|c|c|c|}
\hline \multirow{3}{*}{ Soil map unit } & \multicolumn{2}{|c|}{$\mathrm{Ca}$} & \multicolumn{2}{|c|}{$\mathrm{Mg}$} \\
\hline & Cropland & Grassland & Cropland & Grassland \\
\hline & \multicolumn{4}{|c|}{$\ldots \ldots \ldots \ldots\left(\mathrm{mg} \mathrm{kg}^{-1}\right) \ldots \ldots \ldots$} \\
\hline \multicolumn{5}{|l|}{ Wymore (WtB) } \\
\hline Average & 2949.2 & 3146.3 & 607.8 & 577.4 \\
\hline S.D. & 386.0 & 255.1 & 101.4 & 43.0 \\
\hline \multicolumn{5}{|c|}{ Wymore (WtC2) } \\
\hline Average & 3253.2 & 3466.9 & 705.0 & 571.3 \\
\hline S.D. & 297.2 & 340.1 & 171.7 & 68.8 \\
\hline \multicolumn{5}{|c|}{ Wymore (WtD3) } \\
\hline Average & 3483.6 & 3917.8 & 729.4 & 680.7 \\
\hline S.D. & 655.0 & 496.0 & 68.8 & 189.1 \\
\hline \multicolumn{5}{|l|}{ Pawnee (PaC2) } \\
\hline Average & 3092.8 & 2264.5 & 666.6 & 498.4 \\
\hline S.D. & 481.9 & 510.1 & 134.4 & 137.5 \\
\hline \multicolumn{5}{|l|}{ Pawnee (PaD2) } \\
\hline Average & 2989.3 & 3026.0 & 672.6 & 638.2 \\
\hline S.D. & 472.4 & 453.5 & 213.8 & 60.2 \\
\hline \multicolumn{5}{|l|}{ Nodaway } \\
\hline Average & 3583.8 & 3507.0 & 573.4 & 620.0 \\
\hline S.D. & 1106.2 & 170.0 & 257.8 & 103.1 \\
\hline \multicolumn{5}{|l|}{ Sharpsburg } \\
\hline Average & 3219.8 & 3296.6 & 747.6 & 741.5 \\
\hline S.D. & 394.9 & 297.6 & 118.0 & 137.5 \\
\hline \multicolumn{5}{|l|}{ Mayberry } \\
\hline Average & 3022.7 & 2955.9 & 534.9 & 358.6 \\
\hline S.D. & 500.7 & 552.6 & 109.5 & 8.6 \\
\hline \multicolumn{5}{|l|}{ Colo } \\
\hline Average & 3543.7 & 3426.8 & 603.7 & 601.7 \\
\hline S.D. & 663.1 & 56.7 & 122.2 & 43.0 \\
\hline \multicolumn{5}{|l|}{ Judson } \\
\hline Average & 3243.1 & 2845.7 & 530.8 & 461.9 \\
\hline S.D. & 441.9 & 255.1 & 110.3 & 120.3 \\
\hline \multicolumn{5}{|l|}{ Burchard } \\
\hline Average & 2635.3 & 6172.3 & 478.1 & 395.1 \\
\hline S.D. & 699.6 & 3004.1 & 308.5 & 386.8 \\
\hline \multicolumn{5}{|l|}{ Kennebec } \\
\hline Average & 2628.6 & 2525.0 & 455.9 & 443.7 \\
\hline S.D. & 302.4 & 1020.3 & 120.5 & 266.5 \\
\hline
\end{tabular}

The above calculation (steps 1-5) should be performed on two $N$ values (ie, 0 and 100) to develop a linear regression equation for $\mathrm{Ca}$. The equation describes the relationship between the average exchangeable $\mathrm{Ca} \%$ released from all SMUs (independent variable) and runoff $\mathrm{Ca}$ (milligrams per liter) generated from the entire watershed (dependent variable). In this study, we used the data to develop two linear regression equations for $\mathrm{Ca}$, Eq. (7), and $\mathrm{Mg}$, Eq. (8).

$$
\begin{aligned}
& \text { RunoffCa }\left(\mathrm{mgL}^{-1}\right)=7.988+3.678 \times(\mathrm{Ca} \%) \\
& R_{\text {utnoff }} \mathrm{Ca}\left(m g L^{-1}\right)=4.210+0.719 \times(\mathrm{Mg} \%)
\end{aligned}
$$

\section{Geographical Information Systems Digital Mapping}

Digital maps for water and AEEs losses from agricultural land in WT watershed, Lancaster County, Nebraska, were generated by geographical information systems (GIS) software. The GIS software used was ArcView 9.0 (ESRI, 2004). The input required to generate the map included spatial data layers (soil series and land cover) and the tabular data from both the runoff as well as AEEs (water and elements from soils and concentrations in runoff and leaching water).

The principal spatial data layer used was the Soil Survey Geographic (SSURGO) (USDA/ 
NRCS, 1999). Both the National Land Cover (NLCD, 1992) and National Agricultural Statistics Service (NASS, 2003) spatial layers were used to identify areas of cropland and grassland within the county. Other types of land cover such as urban, forest, water, or marsh were not mapped for the watershed. The proposed technique calculated water and elements losses and element concentrations in runoff water for soils under crop and grass. Thus, GIS mapping of agricultural land in the watershed included data layers for soils and land cover as well as water or soil elements $(\mathrm{Ca}, \mathrm{Mg}$, $\mathrm{Ba}$, and $\mathrm{Sr}$ ).

\section{RESULTS AND DISCUSSION}

\section{Runoff and Reservoir Inflow}

The historic record of monthly rainfall for Lancaster County (NWCC, 2003) was applied in the runoff model (USDA/SCS, 1991) to predict annual runoff amounts. The predicted annual loss of water by runoff $\left(\mathrm{m}^{3} / \mathrm{ha}\right)$ for 12 SMUs under crop and grass in WT watershed is given in Table 2. Generally, the annual loss of water from soil by runoff was higher for cropland than grassland. The predicted average (areaweighted) of annual runoff water was 1122 and $942 \mathrm{~m}^{3} \mathrm{ha}^{-1} \mathrm{yr}^{-1}$ for cropland and grassland, respectively. These results accounted for $15.4 \%$ and $12.9 \%$ of the annual rainfall for cropland and grassland, respectively. Similar values were reported for 13 U.S. soils of humid regions (rainfall $>800 \mathrm{~mm} \mathrm{yr}^{-1}$ ) where the average was $15 \%$ for cropland and $12 \%$ for grassland (Elrashidi et al., 2003).

However, these values (runoff waters as a percentage of the annual rainfall) were relatively higher than those reported for 'Lancaster County, Nebraska, where the watershed is located (Elrashidi et al., 2004). This could be attributed to the slow water infiltration rate (hydrologic group D) for the dominant soils (Wymore, Pownee, and Mayberry) in the watershed. These three soils occupy approximately $80 \%$ of the agricultural land in the watershed.

The results indicated that Wymore-WtC2 SMU, irrespective of the land cover, produced the highest volume of runoff water mainly because of its abundance in the watershed. On the other hand, Kennebec soil, which had very limited area, generated the least volume of runoff water. The total annual loss of runoff water from the 12 major SMUs was 4.15 million $\mathrm{m}^{3}$. The area of the 12 major SMUs (3885 ha) encompassed about $96 \%$ of the entire watershed. When the entire watershed area (4042 ha) was considered, the total annual runoff accounited for 4.31 million $\mathrm{m}^{3}$ of water. The observed average annual inflow to the WT reservoir for a 50-year period between 1951 and 2000 was 4.25 million $\mathrm{m}^{3}$ (USGS, 2001; Elrashidi et al., 2005b). The predicted annual runoff and the observed annual inflow appear in good agreement.

\section{Elements in Water Phase}

The average and S.D. of $\mathrm{Ca}, \mathrm{Mg}, \mathrm{Ba}$, and $\mathrm{Sr}$ in the water phase for 12 major soils (reported as $\mathrm{mg}$ or $\mu \mathrm{g} / \mathrm{kg}$ of soil) under crop and grass in WT watershed are given in Table 3. For cropped soils, $\mathrm{Ca}$ dissolved in water phase ranged between 41.7 and $93.8 \mathrm{mg} \mathrm{kg}^{-1}$ with an area-weighted average of $73.4 \mathrm{mg} \mathrm{kg}^{-1}$ of soil. A wider range of $\mathrm{Ca}$ concentration (33.1$161.0 \mathrm{mg} \mathrm{kg}^{-1}$ ) was observed for grassland. However, the area-weighted average was lower than that of cropland at $63.0 \mathrm{mg} \mathrm{kg}^{-1}$ of soil. For the 12 major soils, irrespective of land cover, the average amount of $\mathrm{Ca}$ in water phase was $70.3 \mathrm{mg} \mathrm{kg}^{-1}$ of soil.

For cropped soils, $\mathrm{Mg}$ dissolved in water phase ranged between 27.2 and $47.6 \mathrm{mg} \mathrm{kg}^{-1}$ with an area-weighted average of $41.4 \mathrm{mg} \mathrm{kg}^{-1}$ of soil. A relatively wider range of $\mathrm{Mg}$ concentration (16.1-54.2 $\mathrm{mg} \mathrm{kg}^{-1}$ ) was observed for grassland. However, the area-weighted average was much lower than that of cropland at 26.9 $\mathrm{mg} \mathrm{kg}-1$ of soil. For the 12 major soils, irrespective of land cover, the average $\mathrm{Mg}$ concentration in water phase was $37.0 \mathrm{mg}$ $\mathrm{kg}^{-1}$ of soil.

Compared with $\mathrm{Ca}$ and $\mathrm{Mg}$, much smaller concentrations were measured for both $\mathrm{Ba}$ and $\mathrm{Sr}$. For soils under crop, $\mathrm{Ba}$ dissolved in water phase ranged between 0.94 and $1.88 \mathrm{mg} \mathrm{kg}^{-1}$ with an area-weighted average of $1.56 \mathrm{mg} \mathrm{kg}^{-1}$ of soil. A relatively wider range of $\mathrm{Ba}$ concentration (0.51-2.15 $\mathrm{mg} \mathrm{kg}^{-1}$ ) was observed for grassland. However, the area-weighted average was lower than that of cropland at $1.09 \mathrm{mg} \mathrm{kg}^{-1}$ of soil. For the 12 major soils, irrespective of land cover, the average amount of $\mathrm{Ba}$ in water phase was $1.42 \mathrm{mg} \mathrm{kg}^{-1}$ of soil.

For cropland, $\mathrm{Sr}$ dissolved in water phase ranged between 0.25 and $0.53 \mathrm{mg} \mathrm{kg}^{-1}$ with an area-weighted average of $0.40 \mathrm{mg} \mathrm{kg}^{-1}$ of soil. A relatively wider range of $\mathrm{Sr}$ concentration 


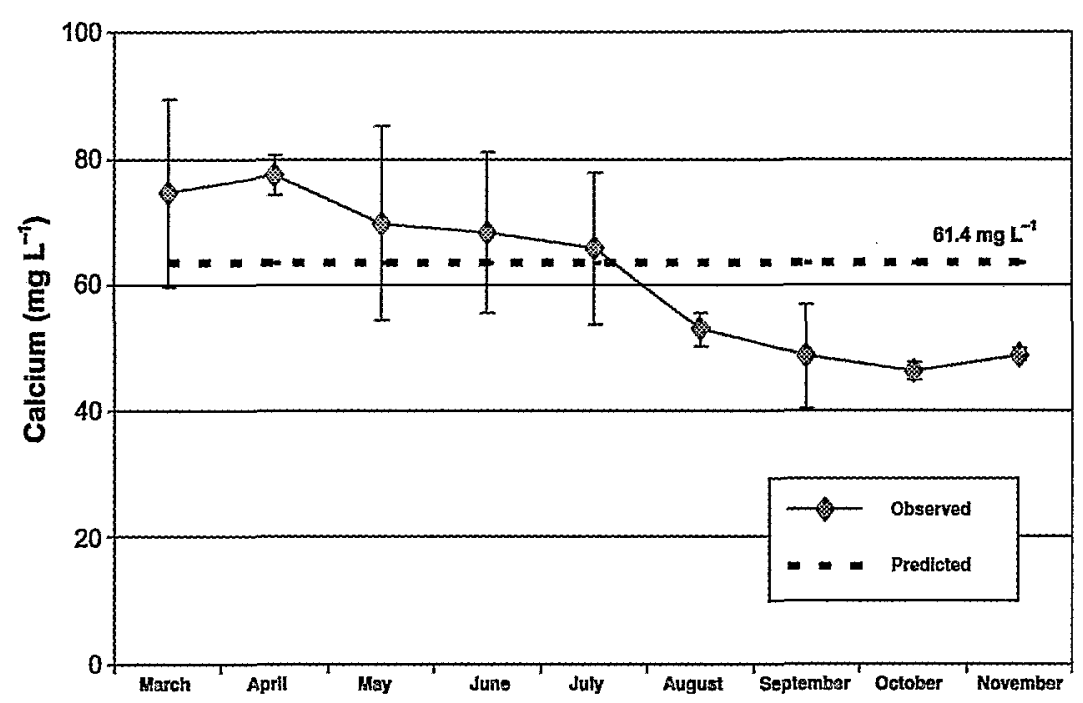

Fig. 2. Predicted $\mathrm{Ca}$ in runoff and observed concentration in stream water for WT watershed.

(0.23-0.66 $\left.\mathrm{mg} \mathrm{kg}^{-1}\right)$ was observed for grassland. Meanwhile, the area-weighted average was similar to cropland at $0.38 \mathrm{mg} \mathrm{kg}^{-1}$ of soil. For the 12 major soils, irrespective of land cover, the average $\mathrm{Sr}$ concentration in water phase was $0.39 \mathrm{mg} \mathrm{kg}^{-1}$ of soil.

\section{Elements in Exchangeable Phase}

The average and S.D. of $\mathrm{Ca}$ and $\mathrm{Mg}$ in the exchangeable phase for 12 major soils (milligrams per kilogram) under crop and grass in WT watershed are given in Table 4. For cropped soils, $\mathrm{Ca}$ in exchangeable phase ranged between 2629 and $3584 \mathrm{mg} \mathrm{kg}^{-1}$ with an area-weighted average of $3199 \mathrm{mg} \mathrm{kg}^{-1}$ of soil. A wider range of $\mathrm{Ca}$ concentration (2265-6172 $\mathrm{mg} \mathrm{kg}^{-1}$ ) was observed for grassland. Meanwhile, the areaweighted average was slightly higher than that of cropland at $3329 \mathrm{mg} \mathrm{kg}^{-1}$ of soil. For the 12 major soils, irrespective of land cover, the average amount of $\mathrm{Ca}$ in exchangeable phase was $3238 \mathrm{mg} \mathrm{kg}^{-1}$ of soil.

For soils under crop, $\mathrm{Mg}$ in exchangeable phase ranged between 456 and $748 \mathrm{mg} \mathrm{kg}^{-1}$ with an area-weighted average of $660 \mathrm{mg} \mathrm{kg}^{-1}$ of soil. Similar range of $\mathrm{Mg}$ concentration (359$742 \mathrm{mg} \mathrm{kg}^{-1}$ ) was observed for grassland. Meanwhile, the area-weighted average was slightly lower than that of cropland at $567 \mathrm{mg}$ $\mathrm{kg}^{-1}$ of soil. For the 12 major soils, irrespective of land cover, the average $\mathrm{Mg}$ concentration in exchangeable phase was $632 \mathrm{mg} \mathrm{kg}^{-1}$ of soil.

Both $\mathrm{Ba}$ and $\mathrm{Sr}$ occur mainly in the water phase whereas negligible amounts were attached to the negatively charged colloid surfaces (exchangeable phase) in soils.

\section{Active Forms of Element in Soil}

Elements dissolved in the soil solution (water phase) within the interactive zone can be removed and lost during the occurrence of runoff event. However, elements attached to the negatively charged colloid surfaces (exchangeable phase) in the soil interactive zone should be released into the water phase before it can be removed by runoff water. It is assumed that energy exerted by raindrops on surface soil (interactive zone) and presence of large amounts of water should enhance the release of cations from the exchangeable to the water phase. The amount of exchangeable element released is dependent upon the intensity and duration of the rainfall event in addition to factors related to the soil properties such as $\mathrm{pH}$, accompanying. cations, and electrical conductivity. Thus, element forms present in both water and exchangeable phases for the soil interactive zone $(10-\mathrm{mm}$ depth) are considered environmentally active.

In this study, approximately $98 \%$ and $94 \%$ of environmentally active $\mathrm{Ca}$ and $\mathrm{Mg}$ are in the exchangeable phase in soils. For $\mathrm{Ba}$ and $\mathrm{Sr}$, however, environmentally active forms are present mainly in water phase because exchangeable forms of these elements are negligible in the 12 soils. Suarez (1996) reported that $\mathrm{Ca}$ and $\mathrm{Mg}$ are the major component of the exchangeable ions, whereas $\mathrm{Ba}$ and $\mathrm{Sr}$ are generally insignificant 


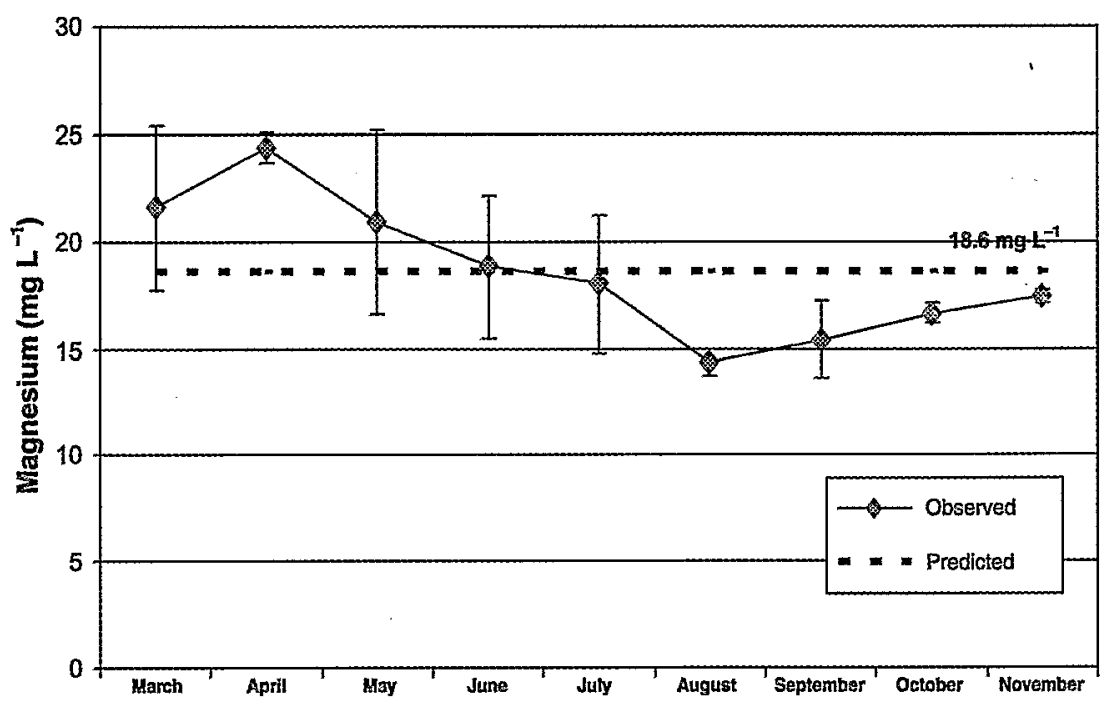

Fig. 3. Predicted Mg in runoff and observed concentration in stream water for WT watershed.

contributors to the sum of the exchangeable cations in soils. For the four elements $(\mathrm{Ca}, \mathrm{Mg}$, $\mathrm{Ba}$, and $\mathrm{Sr}$ ), no apparent differences in the amount of active forms were observed between soils under crop and grass.

\section{Loss of Elements by Runoff}

For the rainy season (March through November), $\mathrm{Ca}, \mathrm{Mg}, \mathrm{Ba}$, and $\mathrm{Sr}$ concentrations were measured in surface water samples collected weekly from the main stream in WT watershed. In this study, we refer to the average element concentration in stream for the rainy season as an annual average. Elrashidi et al. (2005a, 2005b) reported that water samples collected from the main stream in WT watershed are good representative for runoff generated from the entire watershed.

Observed $\mathrm{Ca}$ concentrations in the main stream ranged from 46.3 to $77.4 \mathrm{mg} \mathrm{L}^{-1}$ with an annual average of $61.4 \mathrm{mg} \mathrm{L}^{-1}$ (Fig. 2). Schmidt (2004) reported relatively higher $\mathrm{Ca}$ concentrations ranging between 48 and $120 \mathrm{mg}$ $\mathrm{L}^{-1}$ with an average of $90 \mathrm{mg} \mathrm{L}^{-1}$ in stream

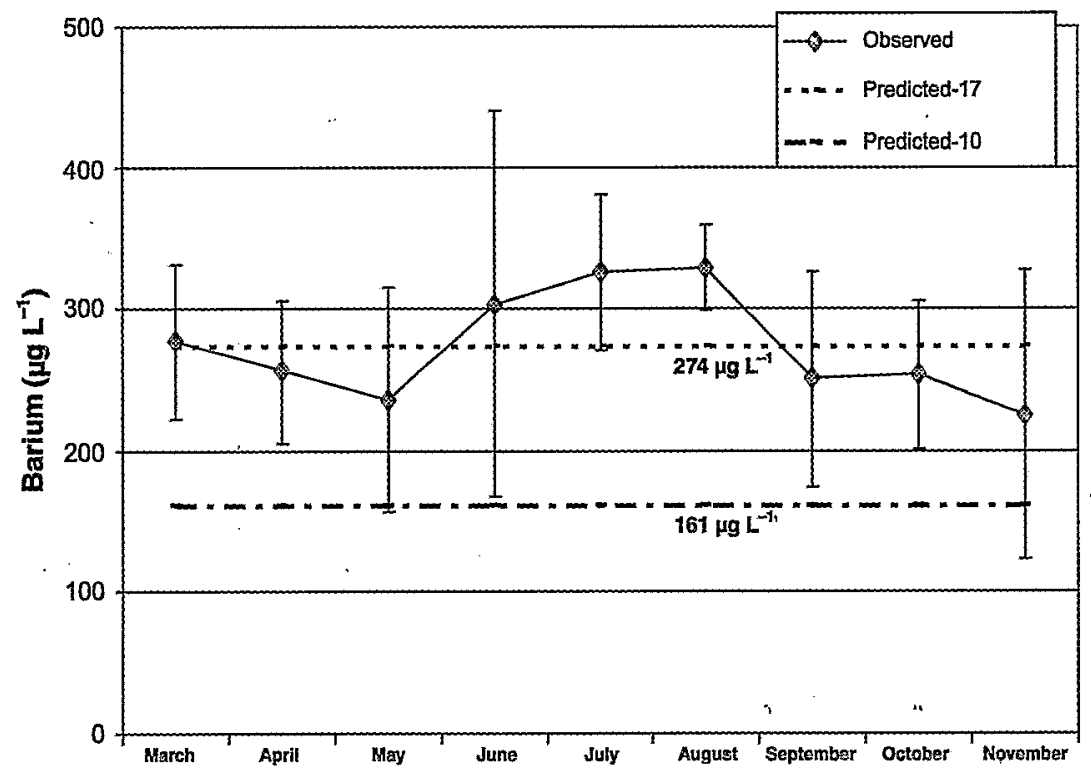

Fig. 4. Predicted Ba in runoff from 10- and 17-mm soil depth and observed concentration in stream. water for , WT watershed. 


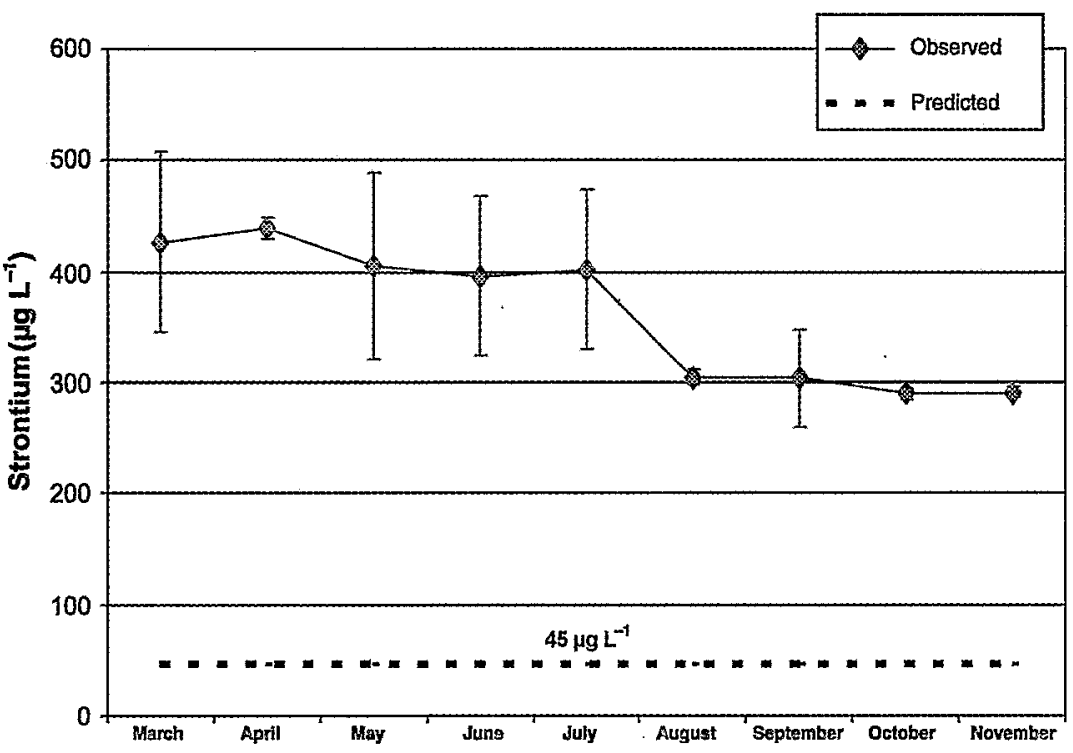

Fig. 5. Predicted Sr in runoff and observed concentration in stream water for WT watershed.

water samples collected from a watershed in northeastern Kansas. In another study on streams in south central Kansas, Christensen (2001) reported wide range of $\mathrm{Ca}$ concentrations between 21 and $100 \mathrm{mg} \mathrm{L}^{-1}$ with an average of $73.0 \mathrm{mg} \mathrm{L}^{-1}$.

In this study, observed $\mathrm{Mg}$ concentrations in water samples collected from WT watershed had a narrow range $\left(14.3-24.4 \mathrm{mg} \mathrm{L}^{-1}\right)$ and averaging $18.6 \mathrm{mg} \mathrm{L}^{-1}$ annually (Fig. 3). These values were similar to those reported for $\mathrm{Mg}$ in northeastern Kansas watershed where the average concentration in streams was $22 \mathrm{mg} \mathrm{L}^{-1}$ (Schmidt, 2004).

In comparison to $\mathrm{Ca}$ and $\mathrm{Mg}$, much smaller $\mathrm{Ba}$ and $\mathrm{Sr}$ concentrations were measured in WT watershed's stream where the average annual concentration was $273 \mu \mathrm{g} \mathrm{L} \mathrm{L}^{-1}$ for Ba (Fig. 4) and $360 \mu \mathrm{g} \mathrm{L} \mathrm{L}^{-1}$ for $\mathrm{Sr}$ (Fig. 5). In their study on Ba for 24 Kentucky streams, Crain (2001) reported a wide range of $\mathrm{Ba}$ concentrations between 0.5 and $480 \mu \mathrm{g} \mathrm{L} \mathrm{L}^{-1}$.

\section{TABLE 5}

Predicted annual loss of $\mathrm{Ca}, \mathrm{Mg}, \mathrm{Ba}$, and $\mathrm{Sr}$ by runoff for 12 major soils under crop and grass in WT watershed, Lancaster County, Nebraska

\begin{tabular}{|c|c|c|c|c|c|c|c|c|}
\hline \multirow{3}{*}{ Soil map unit } & \multicolumn{2}{|c|}{$\mathrm{Ca}^{*}$} & \multicolumn{2}{|c|}{$\mathrm{Mg}^{\dagger}$} & \multicolumn{2}{|c|}{$\mathrm{Ba}^{\ddagger}$} & \multicolumn{2}{|c|}{$\mathrm{Sr}^{\ddagger}$} \\
\hline & Cropland & Grassland & Cropland & Grassland & Cropland & Grassland & Cropland & Grassland \\
\hline & \multicolumn{4}{|c|}{$\ldots \ldots \ldots \ldots\left(\mathrm{kg} \mathrm{ha}^{-1} \mathrm{yr}^{-1}\right)-\cdots \cdots$} & \multicolumn{4}{|c|}{$\ldots-\cdots-\cdots\left(\mathrm{g} \mathrm{ha}^{-1} \mathrm{yr}^{-1}\right) \ldots \ldots$} \\
\hline Wymore (WtB) & 62.48 & 62.94 & 19.32 & 17.60 & 183.67 & 160.2 & 30.3 & 39.49 \\
\hline Wymore (WtC2) & 69.69 & 70.26 & 22.97 & 16.36 & 212.93 & 105.56 & 58.33 & 45.42 \\
\hline Wymore (WTD3) & 69.75 & 81.98 & 22.85 & 23.00 & 229.17 & 259.45 & 43.64 & 79.16 \\
\hline Pawnee $(\mathrm{PaC} 2)$ & 62.52 & 44.99 & 20.10 & 14.77 & 150.25 & 112.93 & 40.14 & 27.73 \\
\hline Pawnee $(\mathrm{PaD} 2)$ & 60.74 & 63.20 & 21.66 & 20.84 & 190.36 & 193.84 & 40.49 & 60.42 \\
\hline Nodaway & 74.22 & 72.41 & 17.41 & 19.37 & 115.98 & 195.05 & 45.36 & 59.59 \\
\hline Sharpsburg & 67.82 & 65.27 & 23.34 & 22.09 & 214.36 & 183.15 & 45.73 & 52.31 \\
\hline Mayberry & 62.88 & 62.01 & 17.73 & 11.25 & 160.43 & 88.88 & 40.12 & 32.78 \\
\hline Colo & 75.58 & 74.76 & 19.08 & 19.53 & 140.45 & 173.97 & 63.66 & 64.69 \\
\hline Judson & 65.73 & 56.42 & 16.26 & 13.20 & 114.21 & 84.07 & 39.77 & 34.58 \\
\hline Burchard & 53.96 & 128.18 & 16.27 & 11.21 & 176.91 & 60.67 & 39.72 & 44.37 \\
\hline Kennebec & 53.16 & 51.29 & 14.52 & 12.67 & 121.93 & 88.8 & 34.09 & 31.11 \\
\hline
\end{tabular}

*Prediction used $\mathrm{Ca}$ ions present in both water phase and $15 \%$ of exchange phase in soils.

${ }^{\dagger}$ Prediction used $\mathrm{Mg}$ ions present in both water phase and $20 \%$ of exchange phase in soils.

${ }^{\ddagger}$ Prediction used Ba or Sr ions present in water phase in soils. 


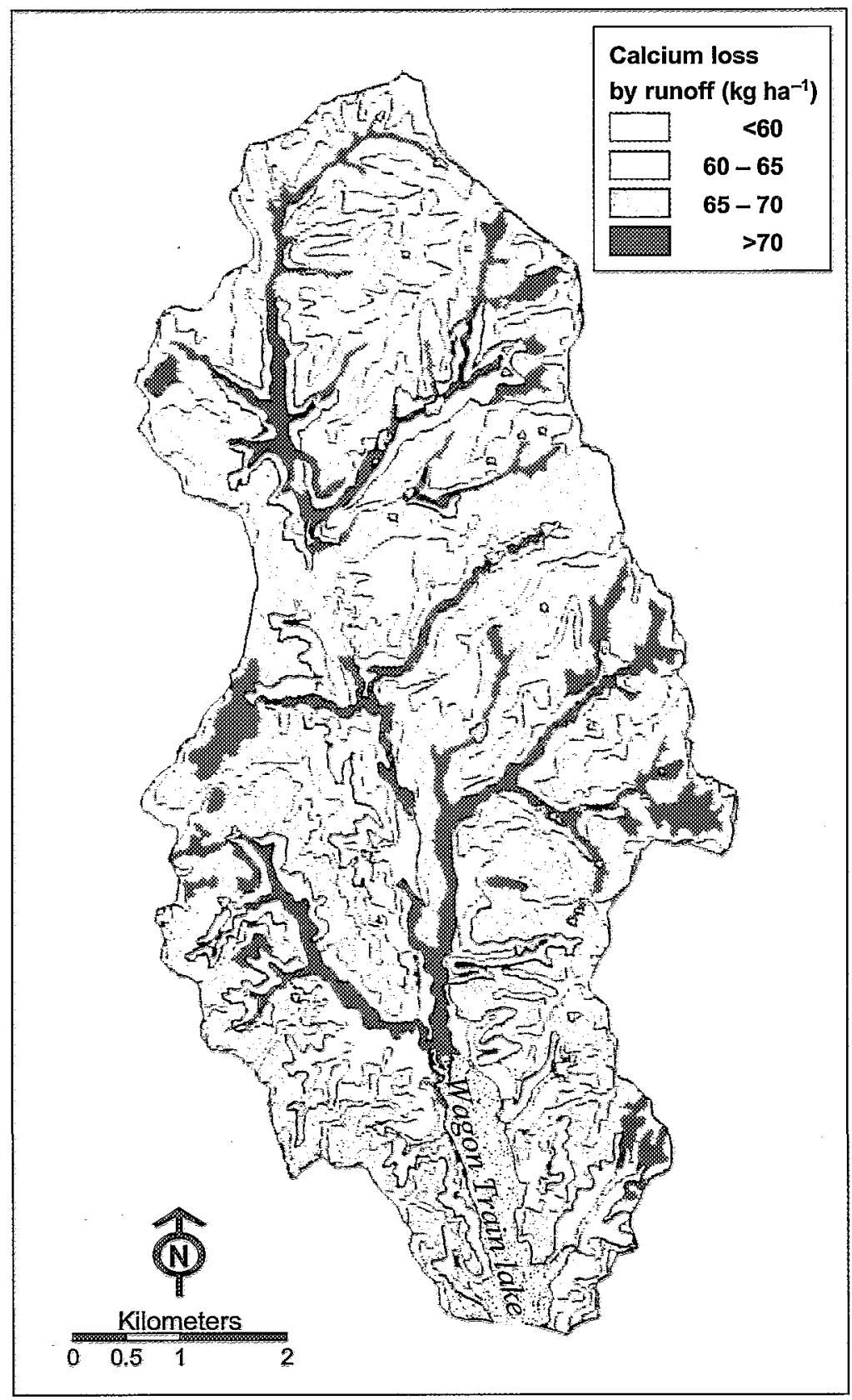

Fig. 6. Calcium loss by runoff from soils in WT watershed, Lancaster County, Nebraska.

We applied the observed annual $\mathrm{Ca}$ concentration (61.4 $\mathrm{mg} \mathrm{L}^{-1}$ ) in Eq. (7) to estimate the percentage of $\mathrm{Ca}$ released from the exchangeable phase in soils. Also, the observed annual $\mathrm{Mg}$ concentration $\left(18.6 \mathrm{mg} \mathrm{L}{ }^{-1}\right.$ ) was used in Eq. (8) to estimate the release from exchangeable $\mathrm{Mg}$. The estimated percentage of exchangeable $\mathrm{Ca}$ and $\mathrm{Mg}$ released, into runoff water, were $15 \%$ and $20 \%$, respectively. We used these percentages to estimate the amount of exchangeable $\mathrm{Ca}$ and $\mathrm{Mg}$ released from the 12 major soils in the watershed. Then, the amount of exchangeable element released was added to the amount of element already present in the water phase to calculate total $\mathrm{Ca}$ and $\mathrm{Mg}$ losses in runoff water. On the other hand, $\mathrm{Ba}$ and $\mathrm{Sr}$ losses in runoff water were driven mainly from elements present in the water phase for soils. The loss of $\mathrm{Ca}, \mathrm{Mg}, \mathrm{Ba}$, and $\mathrm{Sr}$ by runoff water for soils under crop and grass are given as 


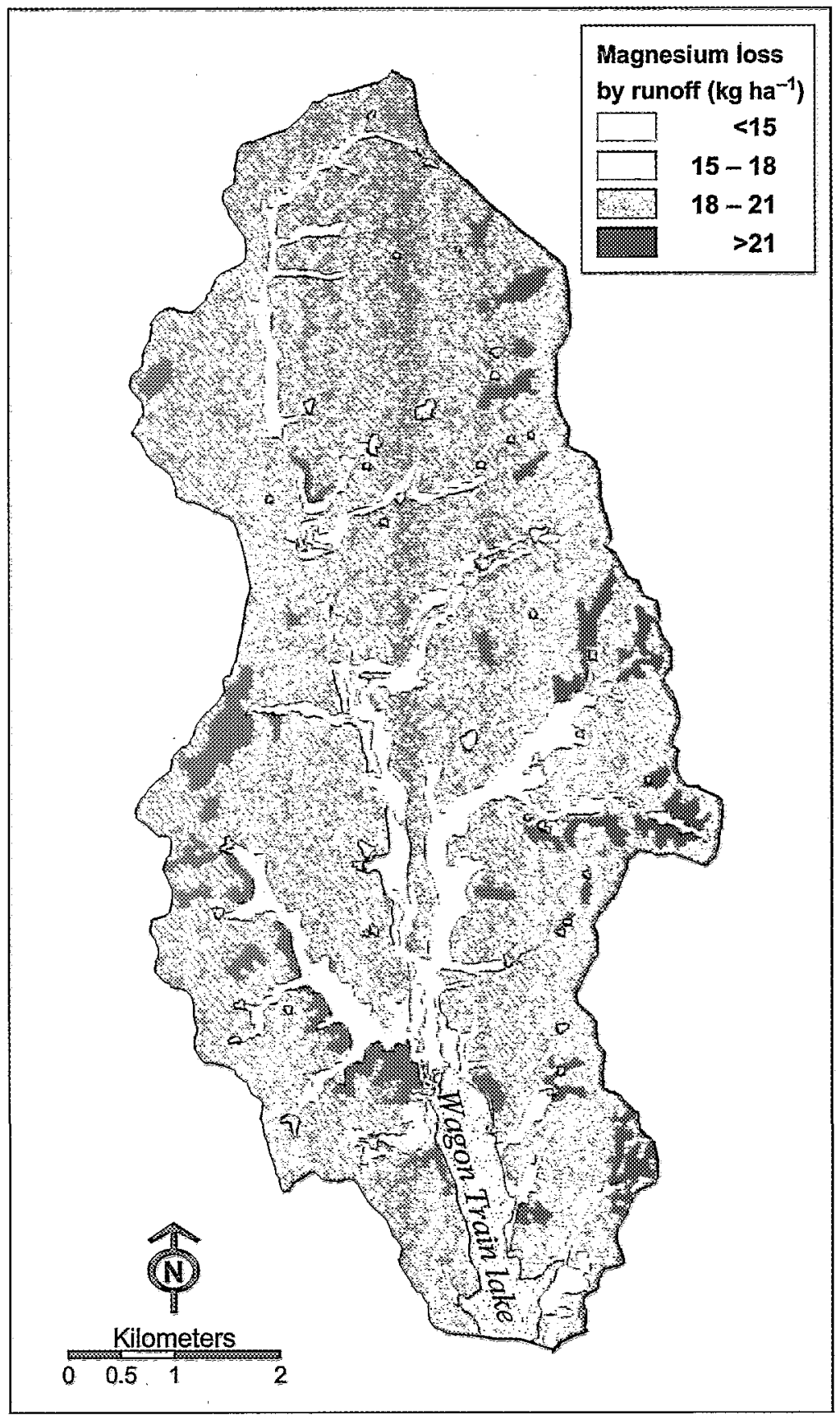

Fig. 7. Magnesium loss by runoff from soils in WT watershed, Lancaster County, Nebraska.

kilograms per hectare ( $\mathrm{Ca}$ and $\mathrm{Mg}$ ) or as grams per kilogram (Bà and $\mathrm{Sr}$ ) in Table 5 .

. As mentioned previously, the loss of $\mathrm{Ca}$ by runoff water (from the $10-\mathrm{mm}$ interactive zone) includes $15 \%$ of cation released from the exchangeable phase in addition to $\mathrm{Ca}$ dissolved in soil solution. For cropped soils, $\mathrm{Ca}$ loss ranged between 53.2 and $75.6 \mathrm{~kg} \mathrm{ha}^{-1}$ with an area- weighted average of $67.4 \mathrm{~kg} \mathrm{ha}^{-1}$. A wider range of Ca loss (45.0-128.2 $\mathrm{kg} \mathrm{ha}^{-1}$ ) was observed for grassland. However, the area-weighted average was similar to that of cropland at $67.8 \mathrm{~kg} \mathrm{ha}^{-1}$. Figure 6 shows Ca loss by runoff (kilograms per hectare) from soils as related to their area and location in the watershed map. Dark areas reflect high $\mathrm{Ca}$ losses $\left(\geq 70 \mathrm{~kg} \mathrm{ha}^{-1}\right.$ ) derived mainly 


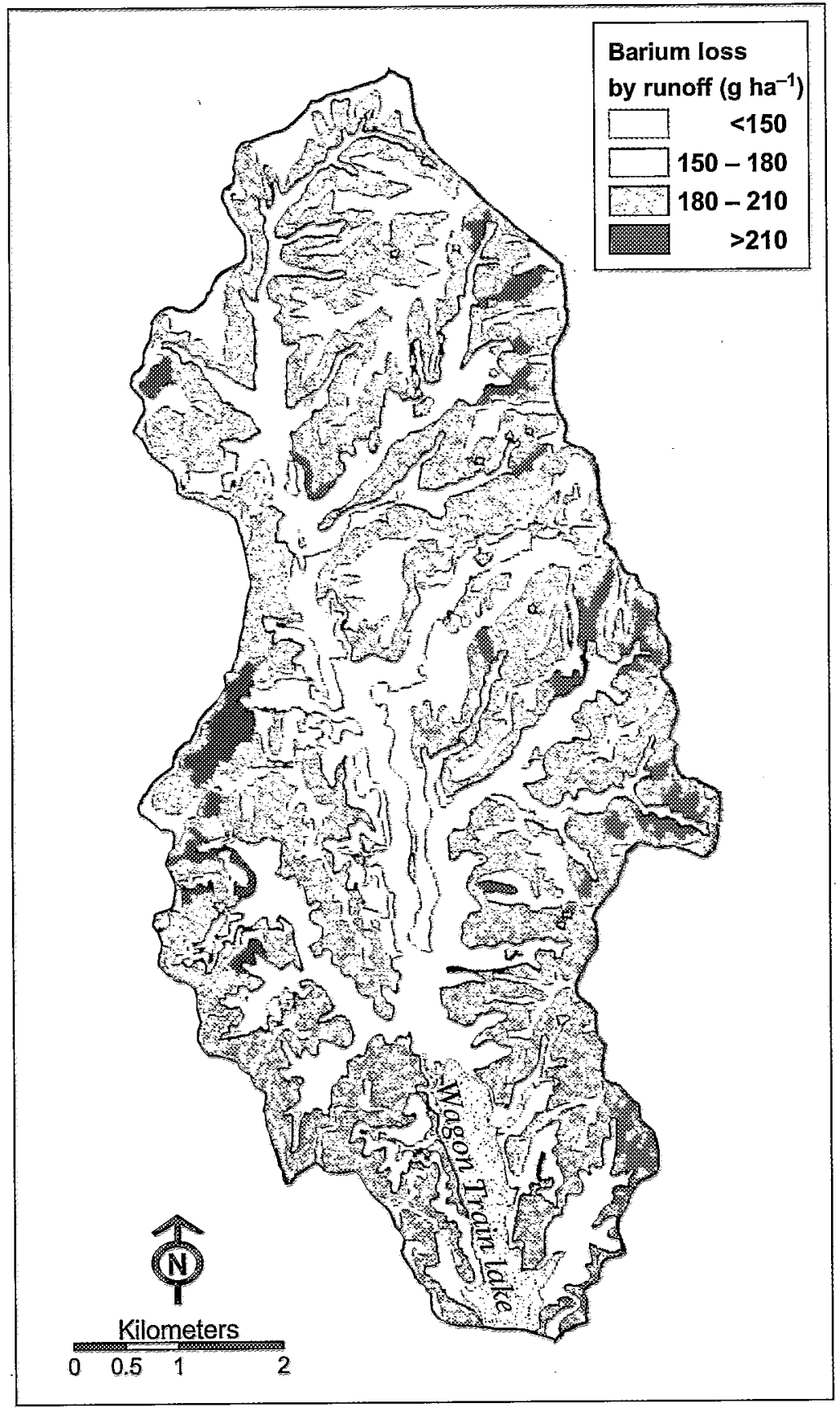

Fig. 8. Barium loss by runoff from soils in WT watershed, Lancaster County, Nebraska.

from Colo and Nodaway soils. For the 12 major soils, irrespective of land cover, the average $\mathrm{Ca}$ loss by runoff was $67.5 \mathrm{~kg} \mathrm{ha}^{-1}$. These data indicate an annual Ca loss of $262 \mathrm{Mg}$ from the 12 major soils in the watershed.

Greater $\mathrm{Ca}$ losses were reported by Crain (2001) in his study on an agricultural watershed in Kentucky where annual losses from soil ranged from 38.6 to $355 \mathrm{~kg} \mathrm{ha}^{-1}$, with an average of $162 \mathrm{~kg} \mathrm{ha}^{-1}$. On the other hand, Timmons et al. (1977), in their study on a forested watershed in northern Minnesota, reported much lesser losses ranging between 3.74 and $4.88 \mathrm{~kg} \mathrm{ha}{ }^{-1}$ with an average of $4.35 \mathrm{~kg} \mathrm{ha}^{-1}$. The high losses from Kentucky watershed could be attributed to the dominance of cropped soils 


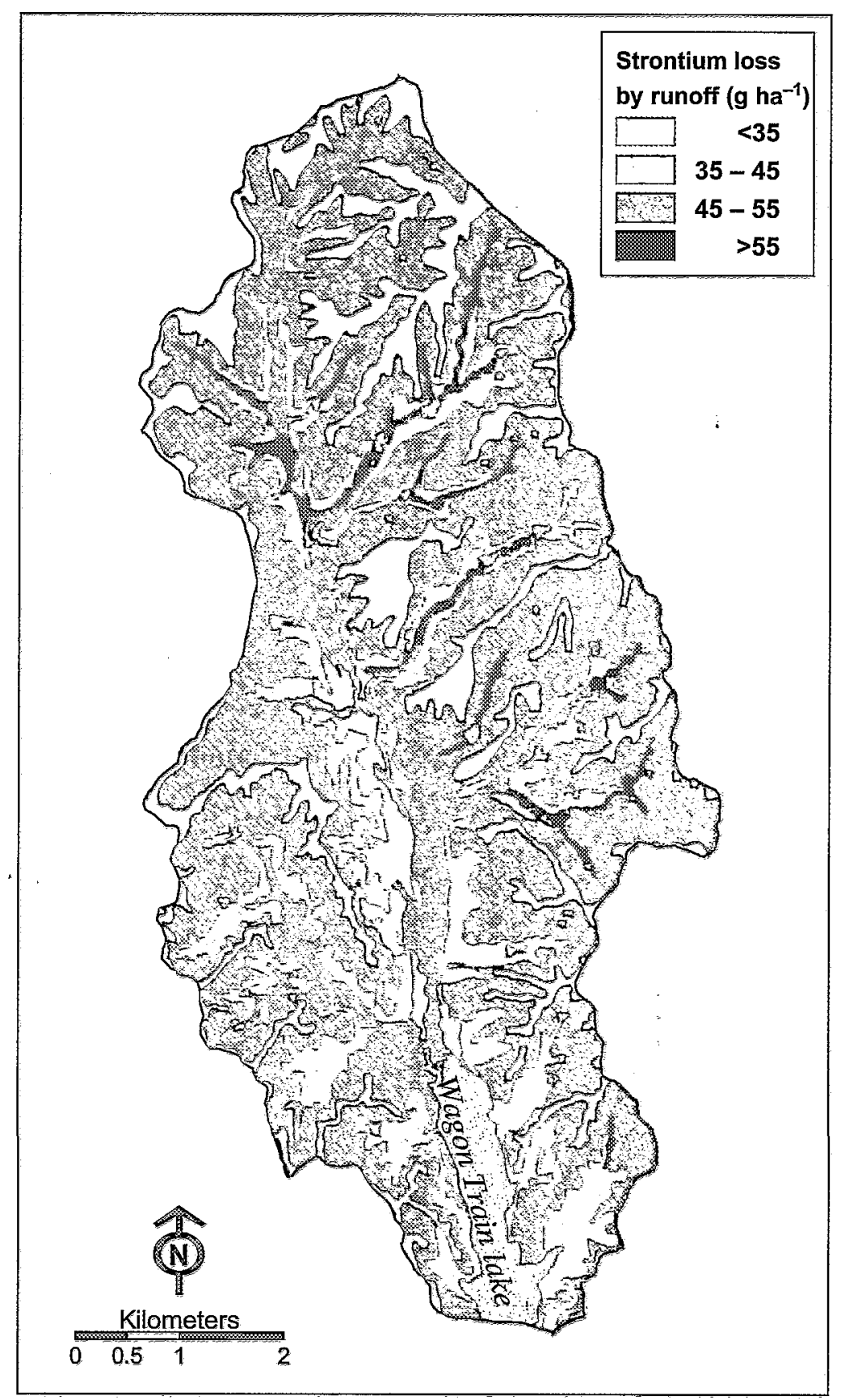

Fig. 9. Strontium loss by runoff from soils in WT watershed, Lancaster County, Nebraska.

amended with lime. On the contrary, acidic forested soils in Minnesota usually have low $\mathrm{Ca}$ contents.

The loss of $\mathrm{Mg}$ by runoff water (from the $10-\mathrm{mm}$ interactive zone) includes $20 \%$ of cation released from the exchangeable phase and $\mathrm{Mg}$ ions dissolved in soil solution. For cropped soils, $\mathrm{Mg}$ loss ranged between 14.5 and $23.3 \mathrm{~kg} \mathrm{ha}^{-1}$ with an area-weighted average of $21.1 \mathrm{~kg} \mathrm{ha}^{-1}$. Similar $\mathrm{Mg}$ losses $\left(11.2-23.0 \mathrm{~kg} \mathrm{ha}^{-1}\right.$ ) were observed for grassland. However, the areaweighted average was lower than that of cropland at $16.9 \mathrm{~kg} \mathrm{ha}^{-1}$. Figure 7 shows $\mathrm{Mg}$ loss by runoff $\left(\mathrm{kg} \mathrm{ha}^{-1}\right)$ from soils in the watershed map. The map shows that a large area in the watershed (consists mainly of Pawnee and 
TABLE 6

Predicted average monthly elements loading by runoff water $(\mathrm{kg})$ into WT reservoir, Lancaster County, Nebraska

\begin{tabular}{|c|c|c|c|c|}
\hline \multirow{2}{*}{ Month } & $\mathrm{Ca}$ & $\mathrm{Mg}$ & $\mathrm{Ba}$ & $\mathrm{Sr}$ \\
\hline & \multicolumn{4}{|c|}{$\ldots-\ldots-\ldots---(\mathrm{kg})-\ldots-\ldots, \ldots$} \\
\hline January & 5796 & 1706 & 15 & 4 \\
\hline February & 6841 & 2013 & 17 & 5 \\
\hline March & 20,712 & 6096 & 53 & 15 \\
\hline April & 28,218 & 8305 & 72 & 20 \\
\hline May & 36,864 & 10,849 & 94 & 26 \\
\hline June & 38,100 & 11,213 & 97 & 27 \\
\hline July & 29,168 & 8584 & 74 & 21 \\
\hline August & 33,159 & 9759 & 84 & 24 \\
\hline September & 32,114 & 9451 & 82 & 23 \\
\hline October & 20,427 & 6012 & 52 & 14 \\
\hline November & 13,017 & 3831 & 33 & 9 \\
\hline December & 8551 & 2517 & 22 & 6 \\
\hline Year & 272,690 & 80,254 & 695 & 193 \\
\hline
\end{tabular}

Wymore soils) generates $\mathrm{Mg}$ losses ranging between 18 and $21 \mathrm{~kg} \mathrm{ha}^{-1}$. For the 12 major soils, irrespective of land cover, the average $\mathrm{Mg}$ loss by runoff was $19.9 \mathrm{~kg} \mathrm{ha}^{-1}$. This gives an annual $\mathrm{Mg}$ loss of $77.1 \mathrm{Mg}$ from the entire watershed. For an agricultural watershed in Kentucky, Crain (2001) indicated that annual $\mathrm{Mg}$ losses ranged from 14.7 to $84.6 \mathrm{~kg} \mathrm{ha}^{-1}$, with an average of $38.6 \mathrm{~kg} \mathrm{ha}^{-1}$. On the other hand, Schreiber et al. (1976) found lesser $\mathrm{Mg}$ losses in runoff water from five southern pine watersheds in northern Mississippi. They found that the average annual loss was $3.05 \mathrm{~kg} \mathrm{ha}^{-1}$.

In this study, the loss of $\mathrm{Ba}$ in runoff water (from the $10-\mathrm{mm}$ interactive zone) includes only $\mathrm{Ba}$ ions dissolved in soil solution. Barium loss ranged between 114 and $229 \mathrm{~g} \mathrm{ha}^{-1}$ with an area-weighted average of $189 \mathrm{~g} \mathrm{ha}^{-1}$ in cropland. A.wider range of $\mathrm{Ba}$ loss (61-259 $\mathrm{g} \mathrm{ha}^{-1}$ ) was observed for grassland. But, the areaweighted average was lower than that of cropland at $131 \mathrm{~g} \mathrm{ha}^{-1}$. Figure 8 shows Ba loss by runoff from soils and their area and location in the watershed map. The map shows that bottom land soils (Kennebec, Nodaway, and Judson) have lesser $\mathrm{Ba}$ losses than other soils in the watershed. For the 12 major soils, irrespective of land cover, the average $\mathrm{Ba}$ loss by runoff was $172 \mathrm{~g} \mathrm{ha}^{-1}$. These data indicate a total annual Ba loss of $668 \mathrm{~kg}$ from the 12 major soils in the watershed. Crain (2001) estimated annual Ba losses in runoff from an agricultural watershed in Kentucky. The average annual loss ranged between 77.2 and $386 \mathrm{~g} \mathrm{ha}^{-1}$, with an average of $270 \mathrm{~g} \mathrm{ha}^{-1}$.
Because of the insignificant amount of exchangeable $\mathrm{Sr}$ in soils, the loss of $\mathrm{Sr}$ in runoff water (from the $10-\mathrm{mm}$ interactive zone) was derived mainly from ions dissolved in soil solution. The loss of Sr by runoff water for soils under crop and grass are given as grams per hectare in Table 5. For cropped soils, Sr losses ranged between 30.3 and $63.7 \mathrm{~g} \mathrm{ha}^{-1}$ with an area-weighted average of $48.8 \mathrm{~g} \mathrm{ha}^{-1}$. A wider range of $\mathrm{Sr}$ losses (27.7-79.2 $\mathrm{g} \mathrm{ha}^{-1}$ ) was observed for grassland. Meanwhile, the areaweighted average was slightly lower than that of cropland at $45.7 \mathrm{~g} \mathrm{ha}^{-1}$. Figure 9 shows $\mathrm{Sr}$ loss by runoff from soils in the watershed map. It shows that large areas in the watershed generate $\mathrm{Sr}$ losses greater than $45 \mathrm{~g} \mathrm{ha}^{-1}$. For the 12 major soils, irrespective of land cover, the average $\mathrm{Sr}$ loss by runoff was $47.8 \mathrm{~g} \mathrm{ha}^{-1}$. This gives an annual total $\mathrm{Sr}$ loss of $186 \mathrm{~kg}$ from the 12 major soils in the watershed.

\section{Elements Loading Into WT Reservoir}

In this study, losses predicted for both water (Table 2) and AEEs (Table 5) by runoff from soils were used to predict AEE concentrations in runoff water. The predicted average $\mathrm{Ca}$ concentration in runoff from soils $\left(63.2 \mathrm{mg} \mathrm{\textrm {L } ^ { - 1 }}\right)$ and the observed average annual concentration in stream water $\left(61.4 \mathrm{mg} \mathrm{L}^{-1}\right)$ were in good agreement (Fig. 2). Meanwhile, a perfect agreement was obtained between the predicted (18.58 $\left.\mathrm{mg} \mathrm{L}^{-1}\right)$ and observed (18.59 $\mathrm{mg} \mathrm{L}^{-1}$ ) $\mathrm{Mg}$ concentrations (Fig. 3). However, the predicted $\mathrm{Ba}\left(161 \mu \mathrm{g} \mathrm{L}^{-1}\right)$ and $\mathrm{Sr}\left(45 \mu \mathrm{g} \mathrm{L}^{-1}\right)$ concentrations in runoff water were lower than those concentrations observed in stream water. The average annual $\mathrm{Ba}$ and $\mathrm{Sr}$ concentrations in stream water were 273 and $360 \mu \mathrm{g} \mathrm{L^{-1 }}$, respectively (Figs. 4 and 5).

In this study, the predicted AEE concentration was calculated for runoff water generated at field sites and not in stream water. Factors affecting AEEs concentration in runoff water after leaving field sites might decrease or increase the observed values in stream water and should be taken into consideration. In previous studies, Elrashidi et al. (2005a, 2005b) reported that $P$ and nitrate- $N$ removal by aquatic weeds and algae in streams has decreased observed concentrations in water. On the other hand, a subsurface seepage that discharge directly into streams might contribute to the high $\mathrm{Ba}$ and $\mathrm{Sr}$ concentrations observed in water samples collected from the main stream. An 
investigation of subsurface seepage was out the scope of this study.

Another approach could be offered to explain these hígh $\mathrm{Ba}$ and $\mathrm{Sr}$ concentrations. In this study, we used a $10-\mathrm{mm}$ topsoil interactive zone to estimate elements removed in runoff water. Increasing the depth of soil interactive zone, where environmentally active $\mathrm{Ba}$ is lost by runoff, from $10-$ to $17-\mathrm{mm}$ soil layer, would increase the average concentration of predicted $\mathrm{Ba}$ in runoff to $273.5 \mu \mathrm{g} \mathrm{L}^{-1}$, which agrees very well with the observed annual $\mathrm{Ba}$ concentration of $273 \mu \mathrm{g} \mathrm{L}^{-1}$ in stream water. However, it is overreaching to apply this approach on $\mathrm{Sr}$ because it would require extending the interaction zone to a depth of $80 \mathrm{~mm}$.

One of the objectives of this study was to estimate the impact of agricultural land on water quality (nonpoint source of $\mathrm{Ca}, \mathrm{Mg}, \mathrm{Ba}$, and $\mathrm{Sr}$ contamination) in WT reservoir. For the agricultural land in WT watershed, we assumed that most of AEEs loss from soils by runoff was transported eventually to WT reservoir. We used the predicted average AEEs concentration in runoff and the predicted volume of monthly surface water runoff to estimate the monthly AEEs loading (kilograms) into WT reservoir (Table 6).

Expectedly, the results indicated that AEEs monthly loading into the reservoir was least during winter (December, January, and February) and averaging 7063, 2079, 18, and $5 \mathrm{~kg}$ for $\mathrm{Ca}$, $\mathrm{Mg}, \mathrm{Ba}$, and $\mathrm{Sr}$, respectively. Most of elements loading in the reservoir occurred during the spring and summer (April through September) because of the rainfall pattern. The average monthly loading were $32,937,9694,84$, and $24 \mathrm{~kg}$ for $\mathrm{Ca}, \mathrm{Mg}, \mathrm{Ba}$, and $\mathrm{Sr}$, respectively. These values show a greater impact for $\mathrm{Ca}$, and $\mathrm{Mg}$ on the water quality in WT reservoir when compared with both $\mathrm{Ba}$ and $\mathrm{Sr}$. The annual.loading was about $273 \mathrm{Mg}$ for $\mathrm{Ca}$ and $80 \mathrm{Mg}$, whereas it was $695 \mathrm{~kg}$ for Ba and $193 \mathrm{~kg}$ for Sr. Crain (2001) estimated $\mathrm{Ca}, \mathrm{Mg}$, and $\mathrm{Ba}$ loads for 22 streams in Kentucky. The average annual loads ranged from 8.2 to 3607 tons for $\mathrm{Ca}, 3$ to 650 tons for $\mathrm{Mg}$, whereas the average annual loads of $\mathrm{Ba}$ ranged between 0.02 and 3.7 tons.

\section{SUMMARY AND CONCLUSIONS}

Nutrients and other water soluble chemicals can be transported from agricultural land by surface runoff and subsurface leaching to freshwater bodies. Management activities on cultivated land in high rainfall areas may pose risk to water quality. An exploratory technique was developed that utilizes existing climatic, hydrologic, and soil survey databases to estimate the loss of nutrients by runoff from agricultural land. The technique applies runoff model to estimate water loss from agricultural watersheds. The interaction between both runoff waters and dissolved elements in root-zone soil is used to estimate element losses from soil. In previous studies, the technique has been applied successfully to estimate phosphorus and nitrate- $\mathrm{N}$ losses from agricultural watersheds. In this study, it was used to estimate losses for AEEs ( $\mathrm{Ca}, \mathrm{Mg}$, $\mathrm{Ba}$, and $\mathrm{Sr}$ ).

For WT watershed, the estimated annual loss of water by runoff was 4.32 million $\mathrm{m}^{3}$. The predicted runoff water was in good agreement with the observed annual inflow for WT reservoir (4.25 million $\mathrm{m}^{3}$ ). Significant losses by runoff from soils in the watershed were predicted for $\mathrm{Ca}\left(67.5 \mathrm{~kg} \mathrm{ha}^{-1} \mathrm{yr}^{-1}\right)$ and $\mathrm{Mg}$ $\left(19.9 \mathrm{~kg} \mathrm{ha}^{-1} \mathrm{yr}^{-1}\right)$. Lower values were predicted for $\mathrm{Ba}$ and $\mathrm{Sr}$ where losses were 172 and $47.8 \mathrm{~g} \mathrm{ha}^{-1} \mathrm{yr}^{-1}$, respectively. Both $\mathrm{Ca}$ and $\mathrm{Mg}$ are essential nutrients for crop production, and their losses should emphasize the need of periodic applications of dolomitic lime on agricultural land.

Water samples have been collected weekly throughout the rainy season (March through November) from the main stream before entering the reservoir. Calcium concentrations in the stream water ranged between 46.3 and $77.4 \mathrm{mg} \mathrm{L}^{-1}$ with an average of $61.4 \mathrm{mg} \mathrm{L}^{-1}$. Magnesium concentrations ranged between 14.3 and $24.4 \mathrm{mg} \mathrm{L}^{-1}$ with an average of $18.6 \mathrm{mg} \mathrm{L}^{-1}$. Barium and $\mathrm{Sr}$ had much lower concentrations, averaging 273 and $360 \mu \mathrm{g} \mathrm{L}^{-1}$, respectively. The predicted annual water and element losses by runoff were used to calculate element concentrations in runoff water. The predicted annual $\mathrm{Ca}$ and $\mathrm{Mg}$ concentrations in runoff from the watershed were 63.2 and 18.6 $\mathrm{mg} \mathrm{L} \mathrm{L}^{-1}$, respectively. Meanwhile, the corresponding $\mathrm{Ba}$ and $\mathrm{Sr}$ concentrations were 274 and $45 \mu \mathrm{g} \mathrm{L}^{-1}$, respectively. The predicted $\mathrm{Ca}$, $\mathrm{Mg}$, and $\mathrm{Ba}$ concentrations in runoff agreed with those observed in stream water. The high $\mathrm{Sr}$ concentration in stream water could be attributed to a subsurface seepage discharging directly into streams in the watershed.

Assuming that most of runoff water from the watershed flows into the reservoir, we used the predicted average annual element concentrations in stream water to estimate annual loadings. The 
estimated annual loading was about 273 and 80 $\mathrm{Mg}$ for $\mathrm{Ca}$, and $\mathrm{Mg}$, respectively, whereas it was $695 \mathrm{~kg}$ for Ba and $193 \mathrm{~kg}$ for Sr. These values were slightly higher (about 4\%) than those predicted for element losses by runoff from soils. This variation could be attributed to using different methods for calculation.

We need to emphasize that the predicted element value was calculated for runoff water generated at field sites and not in stream water. When we consider factors affecting element concentration in runoff after leaving field sites, the technique could provide a reasonable estimation of element concentration in stream water. We concluded that the NRCS technique could be used as an exploratory technique to conduct quick evaluations and identify hot spots (Ba or $\mathrm{Sr}$ ) for large areas of agricultural land. Thus, lengthy and site-specific studies could be focused on certain areas of high risk. With respect to $\mathrm{Ca}$ and $\mathrm{Mg}$ nutrients, the technique could provide useful information for nutrient best management practices.

\section{ACKNOWLEDGMENT}

The authors acknowledge the input from many individuals at the National Soil Survey Center. They are especially grateful to Robert J. Ahrens, director, National Soil Survey Center, for his support during the course of this study. The authors also thank members of the Soil Survey Laboratory: Richard Ferguson, Patty Jones, Jan Lang, Chris Lee, Kathy Newman, Tom Zimmer, Pam VanNeste, and Crystal Schaecher for soil and water analyses.

\section{REFERENCES}

American Society for Testing and Materials (ASTM). 1993. Annual Book of ASTM Standards. Construction. Section 4. Soil and Rock; Dimension Stone. Geosynthesis Vol. 04.08. ASTM, Philadelphia, PA.

Bowen, H. J., and J. A. Dymond. 1956. Strontium and barium in plants and soils. Proc. R. Soc. London. B144:355-368.

Brass, G. W. 1976. The variation of the marine ${ }^{87} \mathrm{Sr} /{ }^{86} \mathrm{Sr}$ ratio during Phanerozoic time: Interpretation using a flux model. Geochim. Cosmochim. Acta. 40:721-730.

Brown, L. E., L. Quandt, S. Scheinost, J. Wilson, D. Witte, and S. Hartung. 1980. Soil Survey of Lancaster County, Nebraska. U.S. Department of Agriculture, Soil Conservation Service, Washington, DC, pp. 1-174.

Christensen, V. G. 2001. Characterization of Surface
Water Quality Based on Real Time Monitoring and Regression Analysis, Quivira National Wildlife Refuge, South Central Kansas. Water Resources Investigations Report 01-4248. U.S. Geological Survey, Lawrence, KS, 28 pp.

Crain, A. S. 2001. Estimated Loads and Yields of Suspended Solids and Water Quality Constituents in Kentucky Streams. Water Resources Investigations Report 01-4075. U.S. Geological Survey, Louisville, KY, $125 \mathrm{pp}$.

Donigian, A. S., Jr., D. C. Beyerlein, H. H. Davis, and N. H. Crawford. 1977. Agricultural Runoff Management (ARM) Model Version II: Refinement and Testing. EPA 600/3-77-098. Environmental Research Laboratory, U.S. Environmental Protection Agency, Athens, GA.

Elrashidi, M. A., M. D. Mays, and P. E. Jones. 2003. A technique to estimate release characteristics and runoff phosphorus for agricultural land. Commun. Soil Sci. Plant Anal. 34:1759-1790.

Elrashidi, M. A., M. D. Mays, S. D. Peaslee, and D. G. Hooper. 2004. A technique to estimate nitrate-nitrogen loss by runoff and leaching for agricultural land, Lancaster County, Nebraska. Commun. Soil Sci. Plant Anal. 35:2593-2615.

Elrashidi, M. A., M. D. Mays, A. Fares, C. A. Seybold, J. L. Harder, S. D. Peaslee, and Pam VanNeste. 2005a. Loss of nitrate- $\mathrm{N}$ by runoff and leaching for agricultural watersheds. Soil Sci. 170:969-984.

Elrashidi, M. A., M. D. Mays, J. L. Harder, D. Schroeder, P. Brakhage, S. D. Peaslee, C. Seybold, and C. Schaecher. 2005b. Loss of phosphorus by runoff for agricultural watersheds. Soil Sci. 170:543-558.

Environmental Systems Research Institute (ESRI). 2004. ArcGIS Version 9.0, ESRI (http://wwww. esri.com, accessed August 2005).

Frere, M. R., J. D. Ross, and L. J. Lane. 1980. The nutrient sub-model. In: CREAMS: A Field Scale Model for Chemicals, Runoff and Erosion From Agricultural Management Systems. W. G. Knisel (ed.). Conservation Report No. 26. U.S. Department of Agriculture, Science and Education Administration, 1:65-86.

Garrels, R. M., and E. A. Perry. 1974. Cycling of carbon, sulfur, and oxygen through geologic time. In: The Sea, Vol. 5. E. D. Goldberg (ed.). WileyInterscience, New York, pp. 3003-3336.

Gilbert, W. A., D. J. Graczyk, and W. R. Krug. 1987. Average Annual Runoff in the United States, 1951-1980. Hydrologic Investigations. National Atlas HA-710. U.S. Geological Survey, Reston, VA.

Hem, J. D. 1989. Study and Interpretation of the Chemical Characteristics of Natural Water, 3rd Ed. Water Supply Paper 2254. U.S. Geological Survey, Washington, DC, 263 pp.

Lower Platte South Natural Resources District (LPSNRD). 2004. A Community-based Watershed 
Management Plan for Wagon Train Lake, Lancaster County, Nebraska. Nebraska Department of Environmental Quality, Lincoln, NE.

National Agricultural Statistics Service (NASS). 2003. U.S. Department of Agriculture, National Agricultural Statistics Service, Washington, DC (http:// www.nass.usda.gov/ne).

National Land Cover Data (NLCD). 1992. National Land Cover Data for Nebraska. Version 05-07-00. Nominal Thematic Mapper (http://landcover. usgs.gov/natllandcover.html, accessed August 2005).

National Water and Climate Center (NWCC). 2003. National Water and Climate Center (http:// www.WCC.NRCS.gov/water/W_CLIM.html, accessed August 2005).

Schmidt, H. C. 2004. Quality of Water on the Prairie Band Potawatomi Reservation, Northeastern Kansas, May 2001 Through August 2003. U.S. Geological Survey, Scientific Investigations Report 2004-5243, Lawrence, KS, 69 pp.

Schreiber, J. D., P. D. Duffy, and D. G. McClurkin. 1976. Dissolved nutrient losses in storm runoff from five southern pine watersheds. J. Environ. Qual. 5:201-205.

Suarez, D. L. 1996. Beryllium, magnesium, calcium, strontium, and barium. In: Methods of Soil Analysis. Part 3. Chemical Methods. D. L. Sparks, A. L. Page, P. A. Hlmke, and R. H. Loeppert (ed.). SSSA Book Series 5. SSSA/ASA, Madison, WI, pp. 575-601.

Timmons, D. R., E. S. Verry, R. E. Burwell, and
R. F. Holt. 1977. Nutrient transport in surface runoff and interflow from an aspen-birch forest. J. Environ. Qual. 6:188-192.

U.S. Department of Agriculture Natural Resources Conservation Service (USDA/NRCS). 2004. Soil Survey Laboratory Methods Manual. Soil Survey Investigations Report No. 42, Version No. 4. USDA/NRCS, Washington, DC.

U.S. Department of Agriculture Natural Resources Conservation Service (USDA/NRCS). 1999. Soil Survey Geographic (SSURGO) Database for Lancaster County, Nebraska (http://www.ftw.nrcs. usda.gov/ssur_data.html, accessed August 2005).

U.S. Department of Agriculture Soil Conservation Service (USDA/SCS). 1991. Estimating runoff and peak discharges. In: National Engineering Field Manual. USDA/NRCS, Washington, DC, pp. 1-19.

U.S. Environmental Protection Agency (USEPA). 1986. Quality Criteria for Water. Report 440/586-001. USEPA, Washington, DC.

U.S. Environmental Protection Agency (USEPA). 2003. National Primary Drinking Water Standards. Report 816-F-03-016. USEPA, Office of Water, Washington, DC.

U.S. Geological Survey (USGS). 2001. Water Resource Data, Nebraska Water Year 2000. Platte River Basin, Lower Platte River Basin, Salt Creek at Roca. Water-Data Report NE-00-1. U.S. Department of the Interior, USGS, Washington, DC, pp. 180-181. 